University of Arkansas, Fayetteville

ScholarWorks@UARK

Graduate Theses and Dissertations

$5-2021$

\title{
Quality Determinates of Rice Price in Open Bag Markets in Sub- Saharan Africa
}

Bailey Peterson-Wilhelm

University of Arkansas, Fayetteville

Follow this and additional works at: https://scholarworks.uark.edu/etd

Part of the Agribusiness Commons, Agricultural Economics Commons, Agricultural Science

Commons, Agronomy and Crop Sciences Commons, and the Food Security Commons

Citation

Peterson-Wilhelm, B. (2021). Quality Determinates of Rice Price in Open Bag Markets in Sub-Saharan Africa. Graduate Theses and Dissertations Retrieved from https://scholarworks.uark.edu/etd/4094

This Thesis is brought to you for free and open access by ScholarWorks@UARK. It has been accepted for inclusion in Graduate Theses and Dissertations by an authorized administrator of ScholarWorks@UARK. For more information, please contact scholar@uark.edu. 
Quality Determinates of Rice Price in Open Bag Markets in Sub-Saharan Africa

\begin{abstract}
A thesis submitted in partial fulfillment of the requirements for the degree of Master of Science in Agricultural Economics
\end{abstract}

\author{
by
}

\title{
Bailey Peterson-Wilhelm
}

Kansas State University

Bachelor of Science in Agriculture, 2019

May 2021

University of Arkansas

This thesis is approved for recommendation to the Graduate Council.

Lawton Lanier Nalley, Ph.D.

Thesis Committee Chair

Alvaro Durand-Morat, Ph.D.

Committee Member
Aaron Shew, Ph.D.

Committee Member 


\section{Abstract}

Weaknesses in the grades and standards system in low-income countries across Sub-Saharan Africa undermine the transparency of agricultural markets. In the Democratic Republic of the Congo (DRC), Ghana and Mozambique rice is predominately sold in open bags and if rice price does not reflect its quality, then inefficiencies may lead to consumer welfare losses. Importantly, it is possible that impoverished communities are priced out of the market due to inflated and inefficient prices. The objective of this study is to examine determinates of rice price by estimating the impact of selected rice quality attributes on rice prices in DRC, Ghana and Mozambique.

We collected 363 rice samples from open air markets in Bukavu (DRC), Nampula (Mozambique) and across Ghana in 2019. Each rice sample was analyzed in a food science lab for the quality attributes: percentage of chalk and brokens, chalk impact, length, and width. We used multiple regression analysis to estimate if and to what extent quality attributes were the drivers of price.

Findings suggest that there are irregularities in the Ghanaian market for broken rice and that regardless of quality, imported rice is priced higher than domestic rice. In the DRC and Mozambique, our results indicate price is driven by length and width in the former and width in the latter.

These results provide valuable insight to policy makers regarding the need for proper labeling and regulation of open bag rice sales in an effort to increase consumer welfare and improve food security. 


\section{Table of Contents}

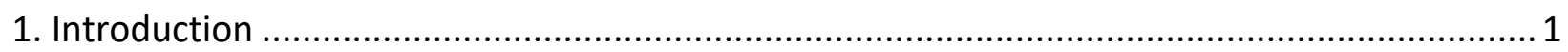

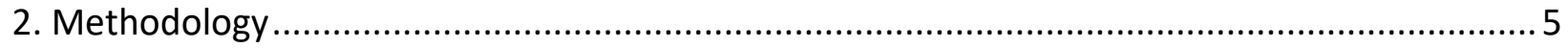

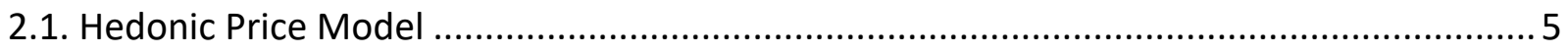

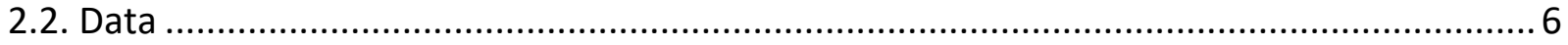

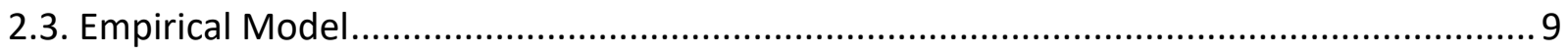

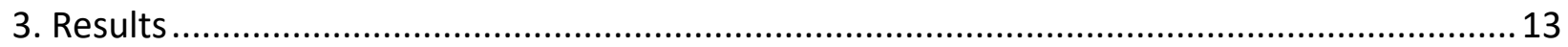

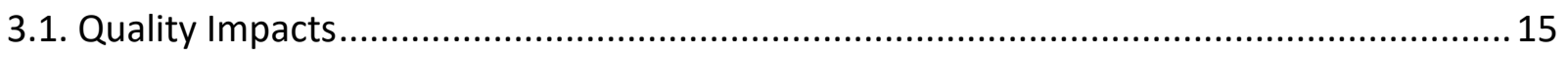

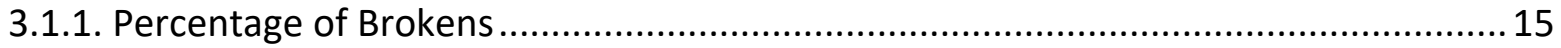

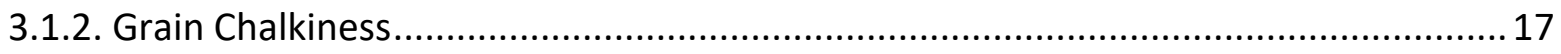

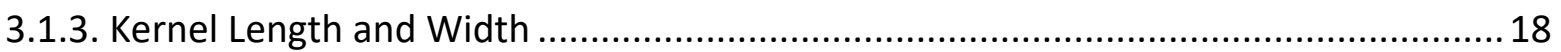

3.2 Value Heterogeneity across African Countries .............................................................. 19

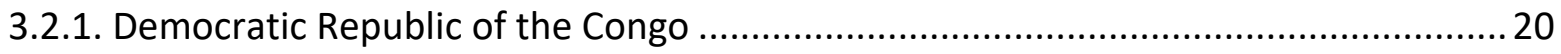

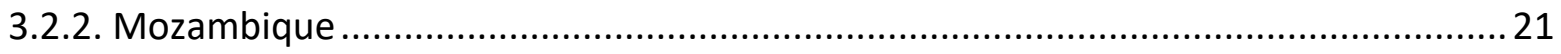

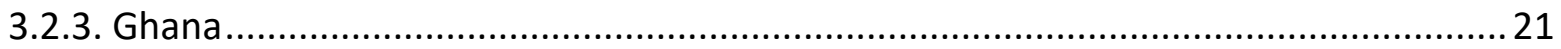

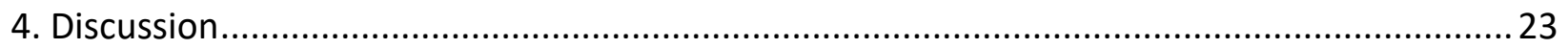

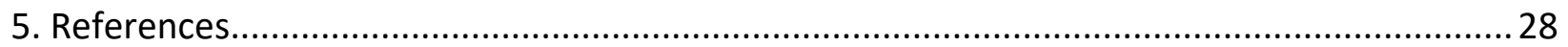

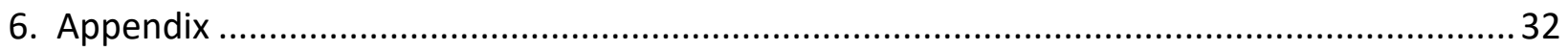

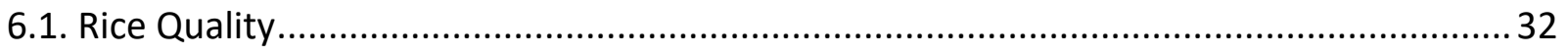

6.1.1. Broken Rice ……................................................................................................. 32

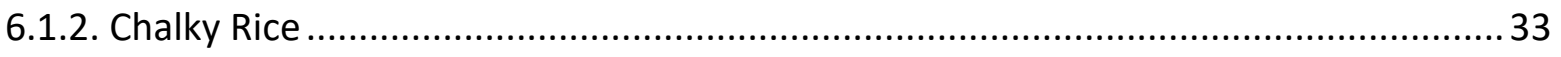

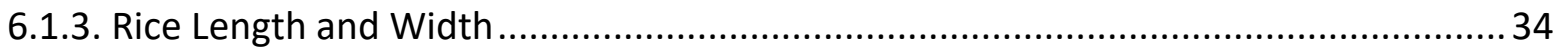

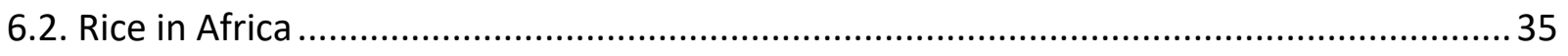

6.2.1. The Democratic Republic of the Congo ..................................................................... 35

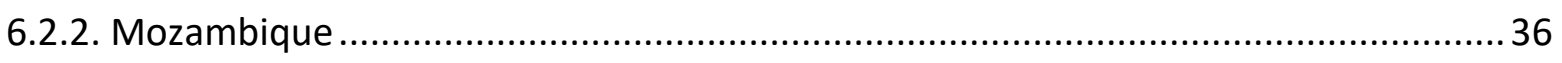

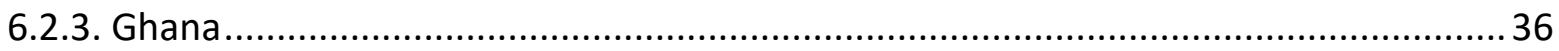

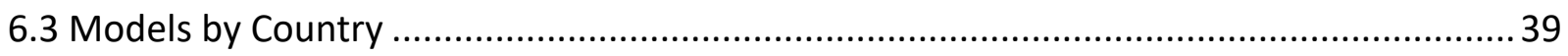




\section{Introduction}

In Sub-Saharan Africa, rice is increasingly becoming an important food crop (Kihoro et al., 2013; Muthayya et al., 2014). Unlike in Asia where the growing middle class is reducing its rice consumption, increased rice consumption is linked to economic development and urbanization across Africa (Nasrin et al., 2015). Although rice is the most important staple in the world, in terms of caloric intake, it is thinly traded on global markets. Only seven percent of total rice production is traded globally ("PS\&D", 2020). This is largely due to the fact that rice is mainly consumed where it is produced, and that rice is still a highly protected commodity. Strict import standards, including limits on the allowable percentage of broken kernels, standards on rice length and percentage of chalky kernels, can also limit trade if they do not closely reflect consumer preferences (Muthayya et al., 2014). High quality importation standards often drive up the price of rice and leave the poorest of the poor vulnerable to food insecurity.

Our study considers the functionality of the open bag rice markets of the Democratic Republic of the Congo (DRC), Ghana and Mozambique. For this study, a market is considered functioning efficiently when rice price (1) is a function of its quality attributes, and (2) has the expected relationship with the quality attributes (e.g., negative relationship between price and percentage of broken kernels, etc.). We aim to estimate which, if any, quality attributes drive market pricing in the open air markets. This study provides a unique perspective on rice in SubSaharan Africa because these three countries represent distinct rice policies and socio-political contexts. All three countries are quickly growing in both population and rice consumption. Sparse literature documents how quality affects rice price in Ghana, and no studies have been conducted for Mozambique and DRC to our knowledge. Unlike Asia, where rice has been 
engrained in daily culture for centuries, rice preferences in Africa are still evolving; specifically as higher quality, imported rice is flooding the continent. Thus, understanding what consumers value is of importance for plant breeders, food security experts, governments and food importers. Rice traders and governments that impose strict import standards on broken rice percentage, as in Nigeria and Haiti, only limits rice consumption to the upper class because such high-quality rice is expensive. This study investigates how markets in three African countries are pricing lower quality (higher chalk and broken percentages (Fitzgerald and Resurreccion, 2009)) rice based on its attributes (see the Appendix for rice quality details). If low quality rice is priced accordingly this could signal that consumers can differentiate quality attributes and import standards could be lowered.

Beyond market motivations, this study also has environmental implications. Irrigated paddy rice is a water-intensive crop, accounting for approximately $25 \%$ of total global annual freshwater usage (Dobermann, 2012). Growing $1 \mathrm{~kg}$ of rice, on average, takes two to three times more water than other cereal grain crops (Tuong et al., 2005; Grassi et al., 2009). Given that two-thirds of the global population are now confronting water scarcity (Mekonnen and Hoekstra, 2016), and the fact that rice uses such large amounts of water, it is environmentally important that all rice goes to human consumption and not to an alternative use. In the U.S. for instance, it is common to use lower quality rice for pet food, thus the water-intensive rice crop does not make it to its intended market. Market pricing and consumer preferences across Africa need further examination to prevent "sub-quality" rice from entering the non-human food chain if low-income countries globally are willing to consume it. A large concern across Africa is the lack of standards and monitoring of open bag markets where there could be 
incentives for wholesalers and merchants to mix high and low quality rice and sell it at high quality prices. If markets do not work efficiently, the presence of low quality rice could erode the market value for high quality rice and cause market failure.

This study addresses several important questions related to rice markets in the DRC, Ghana and Mozambique. First, this study examines the efficiency of rice markets. Efficient rice markets are those where quality attributes are reflected properly in rice prices. A functioning market matches the preferences of consumers with the quality and price of products; therefore, quality attributes consumers' desire, such as lower levels of brokenness and shape (e.g., length and width), should drive price in a functioning rice market. The open-air bag style markets across Africa make it difficult to visually determine rice quality because of the lack of labeling and quality assurance. Thus, the first goal is to assess whether prices reflect actual quality. The innate difficulty for consumers to visually assess the quality of the rice in open bags, which is not labeled at a market, can lead to market failures. Quality attributes like percentage broken and percentage chalk are very difficult to assess for even expert eyes. Inefficient markets can lead to inflated rice prices because the discounts for lower quality are most likely not being accounted for correctly. The inflated prices push the poor out of the market, making them unable to express their demand and participate in the market. This has obvious food insecurity implications as the urban rich often drive rice markets in many lowincome countries (Demont et al., 2013).

If markets are working efficiently, consumer preferences can be efficiently expressed. Thus, the second goal of this study is to determine which quality attributes are the major drivers of price in each country. While this study does not specifically estimate willingness-to- 
pay (WTP), it does use the proxy of availability of various qualities of rice in markets as a signal that demand exists. By assuming in a functioning market that quality and price will match consumers preference, we can determine which quality attributes are valued by consumers based on availability and price in the open bag market.

Our primary attribute of interest is the percentage of broken rice. If consumers indicate indifference to brokens (proxied by insignificant or minimal price impacts), then there is an opportunity to segment the market accordingly. Offering more choices for percentage of broken rice allows consumers to purchase the rice that best meets their preferences and as importantly for food security in Africa - their budgets. Segmenting the market allows consumers to spend what they are willing and able to cover their rice demand. Nutritionally speaking, broken and whole kernels are nearly identical and have the same starch and protein content (Wang et al., 2002). If it is found that brokens play no role in rice price then it provides important evidence that brokens should not be a constraint to importation.

Rice exporting countries will benefit from this study in three aspects. First, knowing the quality attributes that drive price across the three countries allows exporters to send the rice with specific attributes to specific countries. Secondly, broken rice can be sold at a higher price if consumers are indifferent to percent broken, which can increase the revenue exporters get from broken rice that would otherwise be sold as $100 \%$ broken rice for human consumption, or for non-consumption uses (e.g., pet food or brewing). Increasing the percent of broken rice exported could be particularly helpful for large Asian rice exporters, such as Thailand and India, with a significant presence in these African markets and large volumes of broken rice available. To illustrate, India and Thailand exported an average of 11 and 9 million metric tons of $100 \%$ 
broken rice a year in the period 2015-2019 (“UN COMTRADE", 2020), some of which could be sold at a higher price to consumers indifferent about percent broken. Lastly, rice demand can increase as the market matches more closely the preferences of consumers, including those potentially priced out of the market due to inefficient pricing.

Our study is unique because it takes the qualitative attributes of rice for consumers and systematically quantifies them through analysis in a food science rice lab. We specifically consider quality attributes that can be seen visually (search variables: brokens, chalkiness, length, and width) rather than physicochemical (amylose, texture, stickiness, etc.) attributes that cannot be determined without advanced analysis. This research gives insight into a rapidly growing staple crop in three rapidly growing countries. There is little in the way of previous rice attribute studies in Mozambique and DRC and while literature does exist for the Ghanaian market it does not specifically address the drivers of rice price (see the Appendix for country details). This study can benefit rice exporters, rice policy makers, food security advocates, rice scientists and rice consumers by exploring what attributes drive rice price in each respective country.

\section{Methodology}

\subsection{Hedonic Price Model}

Hedonic pricing assumes that the demand for goods is derived from the demand for specific attributes, or similarly, that a product is a basket of attributes, each contributing to the product's market price. Hedonic price models are rooted in Lancaster theory of demand that states that a product can be described as a bundle of characteristics or attributes (Lancaster, 1971). Consumers choose which product to buy based on the bundle of attributes embedded in 
the product, and the price they pay is considered the revealed WTP for a product (Lusk and Shogren, 2007). Formally, we define the hedonic price model as:

$$
P_{i}=\sum_{k} \alpha_{k} X_{k, i}+\varepsilon_{i}
$$

where $P_{i}$ is the market price for rice type $i, X_{k, i}$ is vector of selected quality variables $k$ for rice type $i, \alpha_{k}$ is a vector of parameters, and $\varepsilon_{i}$ is the error term.

\subsection{Data}

Long grain non-fragrant rice samples were collected from ten markets across Bukavu, DRC (the sixth largest city in DRC and the capital of South Kivu province) in the summer of 2019. A total of 101 samples (each roughly $100 \mathrm{~g}$ ) were purchased in open-air markets by the same participant who purchased the rice at all the markets in Swahili. At the point of purchase the price of the rice, in Congolese Franc (CDF), was recorded along with the weight of the rice (so we could standardize price per $\mathrm{kg}$, as rice in DRC is sold in open bags and distributed by scooping cups of various sizes into a bag). All the collected samples were imported to DRC and non-parboiled.

Long grain non-fragrant rice samples were collected from nine markets across Nampula, Mozambique (the third largest city in Mozambique and capital of the Nampula province) in the summer of 2019. 112 samples (roughly $100 \mathrm{~g}$ ) were purchased in open-air markets by the same participant who purchased the rice at all markets in either Portuguese or Makua (the local tribal language). Prices per kg were labeled on/in each bag in Mozambican metical (MZN) which the data collector noted with each sample. Like the DRC samples, all the collected samples were imported and non-parboiled. 
Long grain non-fragrant rice samples were collected from 14 markets across Ghana (10 clustered around Accra and four in northern Ghana) between July and August of 2019. A total of 150 samples were collected. The majority of the transactions were done in the Akan dialect, with a few in English. Local units such as "olonka", "American tin cup", or "margarine tin" were used in purchasing each sample. These local units consist of empty cans or plastic containers with varying sizes that reflects the price, which was known prior to the purchase through signage. Similar to the DRC samples, in Ghana prices were determined by container size. Subsequently, the per kg price at which the samples were bought were calculated as the quotient of its purchase price divided by its kg equivalence determined with an electronic weighing scale. Each sample was also labeled as imported or domestic and parboiled or nonparboiled.

In each of the three countries there was no negotiation in price, as the price for each type of rice in each location was delineated with signage. Prices in Mozambique were labeled per kg, in DRC and Ghana it was labeled by scoop (of various sizes which necessitated weighing each sample to get its per $\mathrm{kg}$ price). As is common in many African open market some vendors may put more rice the top of the premeasured cup (mitigated by the weighing and standardizing of each sample) but this was not negotiated and each sample was purchased at its per scoop value. While bargaining is common in many African markets, its less prevalent when prices are labeled. While not attempted for the reasons listed above, if bargaining did take place it was our a priori expectation that the relative difference in "bargained" prices would be equivalent to the labeled prices. 
A potential criticism of the sampling by convenience method employed in this study is that the samples collected may not represent what consumers are actually buying and the price they pay since prices and quantities purchased by consumers were not observed. That is, consumers in one city may buy the majority of their rice from one vendor and it may be one specific type of rice. In an attempt to mitigate this we purchased rice from multiple vendors in each market and went to several markets in each of the focus areas. Further, given that rice price was labeled and negotiation not common, we approximately know what consumers would pay if they purchased each type of rice. The explicit goal of the study is not to estimate the WTP for rice but rather determine which, if any, quality attributes drive the price of rice that vendors charge.

All rice samples were analyzed in the Rice Processing Lab at the University of Arkansas. The SeedCount Image Analysis System, which is manufactured by Next Instruments (“Next Instruments", 2020), was used to analyze each of the individual samples. From each sample, we used a random 20 grams to estimate various quality attributes. The SeedCount method used this 20-gram sample to create a sub-sample for processing a 500-kernel sample and employed a flatbed scanner to create a digital image of each individual rice kernel. Kernel-by-kernel data was taken for each of the 500-kernel samples and then aggregated for an average score per sample. The SeedCount terminal setup uses a tray with individual slots for each of the 500kernel sample with half of the kernels laying horizontally, allowing for a width measurement, and the other half laying vertically to measure length.

The SeedCount image analysis software uses a comparison of each kernels length with the average sample length to determine broken percentage (defined as less than three-fourths 
the sample average length). Broken and head (whole kernel) rice are the result of milling the hull and bran from the rough rice. Percentage broken is thus measured as the percent weight of a rice sample less than three-fourths the average sample length relative to the original rough, unmilled rice weight (see the Appendix for further details on rice quality measurements). Chalky areas in rice grains, the opaque white parts of the grains, are deemed, generally, to represent poor quality in many rice market segments and thus can result in lower prices and demand (Fitzgerald and Resurreccion, 2009). Chalky areas in rice grains are caused by loose packing or incomplete filling of starch granules (Singh et al., 2003) . SeedCount further quantifies rice chalkiness for each sample as chalk impact (rated from 0-100). Thus, from the SeedCount results we could quantify many of the search attributes deemed important for consumers in the three target countries; width, length, percent broken and chalkiness for each of the 363 total rice samples. Although cleanliness has been cited as a relevant search attribute in Ghana (Sedem et al., 2017), and may likely be a relevant attribute in DRC and Mozambique, the overwhelming majority of the rice samples collected in the three countries were clean, which led us to exclude cleanliness from the model due to lack of data.

\subsection{Empirical Model}

The variables included in all three datasets were identified as: length $(\mathrm{mm})$, width $(\mathrm{mm})$, length-to-width ratio, percent broken, percent chalky, and chalk impact (ranging from 0 to 100). Using available variables, multiple regression analysis was used to estimate the impact of each quality attribute on the observed price. We used a log-log model so that the coefficients could be interpreted as elasticities to determine relative importance of quality attributes for determining rice prices. Seven models, consisting of different combinations of the independent 
variables, were estimated for each of the five scenarios: 1) Ghana total, 2) Ghana imported, 3) Ghana domestic, 4) DRC total and 5) Mozambique total, giving a total of 35 models estimated which are available in the Appendix. The same models were run for each country to allow for comparison. The models estimated for each country show the consistency in significance level of relevant variables along with limited variability in significant coefficients. The models included variations of all available quality characteristics. The quality characteristics specifications and justifications are described below.

While the human eye most realistically looks at rice kernels as a length-to-width ratio, by decomposing the commonly used length-to-width ratio into its parts we can capture whether a specific attribute is driving the price. That being said, all models were estimated using both length and width as well as the length-to-width ratio.

Chalk has several definitions in the international market. There are differences between percent chalky kernels (which is used as the metric of grading in the U.S.) and chalk impact (which we use in this study). The U.S. rice quality standard defines a chalk kernel as one with one-half or more of its area chalky. The percentage of chalk rice in a sample is the percentage weight of chalk kernels over the total weight of the sample. Chalkiness as we define it in this study, using the chalk impact measure, is the total area of a sample which is chalky. Assume there were 100 kernels of rice and every kernel was forty percent chalky. According to the U.S. rice standard, this would result in a sample being zero percent chalky as every kernel in the sample is under the threshold of fifty percent. Under our definition, this sample would be 40 percent chalky because it is total area with no thresholds. Our measurement also has flaws, if there were 10 kernels and 9 had zero chalk but one was 100 percent chalk our modeling would 
say the sample is 10 percent chalky, although the other nine kernels are perfect. Chalk impact usually, though not always, gives a larger value of chalkiness. Regardless of which measure of chalkiness was used the results were similar. The zero values of chalk impact were replaced with a near zero number $\left(1.0 \times 10^{-35}\right)$ to allow for taking logs. The nature of our study requires analyzing a sample of a purchased sample, meaning a zero value of chalkiness from the lab analysis likely translates to a very low level of chalkiness in the open bag of rice available to consumers, that is not exactly zero. For this reason, we feel the replacement of zero's in the data is a reasonable assumption.

In Ghana, where parboiled rice is prevalent and has been shown to affect price we included a dummy variable for parboiled. Further, unlike in DRC and Mozambique where all samples were imported, Ghana had imported and domestic samples that were disaggregated into their own regression. Because previous literature has found that Ghanaians prefer imported to domestic rice, ceteris paribus, we wanted to test this hypothesis by estimating domestic and imported rice separately. By running three separate models by country (and two for domestic and imported rice in Ghana), rather than including fixed effects dummies, we allow flexibility of each quality attribute to vary by country.

Fixed effects for markets were tested in each country (shown in Appendix). The significance of the market binary variables varied by country, but the coefficients of the quality attributes remained largely unchanged after the inclusion of market fixed effects. Including the market fixed effects, ranging from nine to 14 markets, decreased degrees of freedom without providing any new insights. It would stand to reason that rice is more homogeneous in quality attributes within a market as opposed to across markets, as vendors in a market may purchase 
from the same wholesalers. If this is the case then the market fixed effects could be capturing some of the explanatory power of the rice quality variables. As such, we pooled all markets together, by country, in the preferred model. Unlike the DRC and Mozambique, where samples were collected within the same city, in Ghana samples were collected in and around Accra as well as the North of the country. To account for spatial preferences or transportation cost differences, each model for Ghana included a locational fixed effect for Accra or "other". The preferred model was selected based on the above justifications, while also considering adjusted $\mathrm{R}^{2}$ and AIC comparisons. Of the five scenarios without markets, consisting of Ghana total, Ghana imported, Ghana domestic, DRC total, and Mozambique total, the preferred model provided the highest $\mathrm{R}^{2}$ in four out of the five models. The consistency in our preferred model across the countries in this study allows for comparison of elasticities. The preferred model for DRC and Mozambique is as follows:

$$
\begin{gathered}
\log (\text { Price })=\beta_{0}+\beta_{1} \log (\text { Broken })+\beta_{2} \log (\text { Length })+\beta_{3} \log (\text { Width }) \\
+\beta_{4} \log (\text { Chalk Impact })+\varepsilon
\end{gathered}
$$

And the following equation for Ghana:

$$
\begin{aligned}
\log (\text { Price })= & \beta_{0}+\beta_{1} \log (\text { Broken })+\beta_{2} \log (\text { Length })+\beta_{3} \log (\text { Width }) \\
& +\beta_{4} \log (\text { Chalk Impact })+\beta_{5} \text { Parboiled }+\varepsilon
\end{aligned}
$$

After the preferred model was estimated, the results for each country were tested for homoscedasticity using the Breusch-Pagan test. If the model was found to be heteroscedastic, the heteroscedasticity consistent covariance matrix was estimated using HC3 as in Long and Ervin (Long and Ervin, 2000) due to our small sample size. Robust standard errors from HC3 correction were obtained using $\mathrm{R}$ version 4.0.2 and the sandwich package and the Imtest 
package (Zeileis, 2004; Zeileis and Hothorn, 2002). Models were also checked for multicollinearity, given the relationship between brokenness and chalkiness, using the variance inflation factor (VIF) function in the car package in R. None of our models indicated multicollinearity, defined as having a VIF above a threshold of ten. Additionally, the data was examined for breakpoints in the brokenness variable slope using piecewise linear regression and breakpoint analysis. This would reveal any thresholds of significance in brokenness, for example revealing that brokens are only significant above $15 \%$. The analysis was done using the segmented function in the segmented package in R. However, no significant breakpoints or thresholds were identified indicating that rice price and broken percentage had a linear relationship.

\section{Results}

Summary statistics for the quality attributes found through the SeedCount analysis are presented in Table 1. The absolute differences in maximums and minimums for length and width appear to be relatively small, but this is due to the physiological properties of long grain rice, a kernel can only get so long and so wide. That being said, the relative differences between the maximum and minimums ranged from 12 to 35 percent. On average, the Mozambican sample had the largest kernel length at $7.01 \mathrm{~mm}$ and domestic Ghanaian sample had the largest width at $2.49 \mathrm{~mm}$. There is greater variation in both the measure of chalkiness and percent broken kernels. The lowest broken percentage was zero from a domestic Ghanaian sample and the highest was $40.4 \%$ from an imported Ghanaian sample. Chalkiness ranged from zero in both a Ghanaian domestic and imported sample to 85.48 in a domestic Ghanaian sample. On average the Ghanaian domestic rice was of lower quality in all categories (shorter, more chalky, 
and with more broken) besides kernel width. This result is consistent with previous studies (Ayeduvor, 2018, 2020; Demont et al., 2013), which found that Ghanaian rice was of lower quality relative to imported rice.

Table 1. Summary statistics for quality attributes

\begin{tabular}{|c|c|c|c|c|c|}
\hline & DRC & Mozambique & $\begin{array}{l}\text { Ghana } \\
\text { (Total) }\end{array}$ & $\begin{array}{c}\text { Ghana } \\
\text { (Domestic) }\end{array}$ & $\begin{array}{c}\text { Ghana } \\
\text { (Imported) }\end{array}$ \\
\hline \multicolumn{6}{|l|}{ Price (USD) ${ }^{*}$} \\
\hline Min & 0.59 & 0.49 & 0.37 & 0.37 & 0.56 \\
\hline Mean & $0.79^{a}$ & $0.67^{b}$ & $1.03^{c}$ & $0.97^{d}$ & $1.06^{\mathrm{cd}}$ \\
\hline Max & 1.34 & 0.98 & 2.04 & 1.91 & 2.04 \\
\hline \multicolumn{6}{|l|}{ Length (mm) } \\
\hline Min & 5.88 & 5.77 & 5.69 & 6.08 & 5.69 \\
\hline Mean & $6.87^{\mathrm{a}}$ & $7.01^{b}$ & $6.86^{\mathrm{a}}$ & $6.71^{\mathrm{c}}$ & $6.94^{\mathrm{ab}}$ \\
\hline Max & 7.56 & 7.6 & 7.73 & 7.36 & 7.73 \\
\hline \multicolumn{6}{|l|}{ Width (mm) } \\
\hline Min & 2.2 & 2.19 & 2.13 & 2.23 & 2.13 \\
\hline Mean & $2.29^{a}$ & $2.32^{\mathrm{b}}$ & $2.37^{c}$ & $2.49^{d}$ & $2.29^{a}$ \\
\hline Max & 2.47 & 2.6 & 2.61 & 2.61 & 2.58 \\
\hline \multicolumn{6}{|l|}{ Broken (\%) } \\
\hline Min & 0.5 & 1.5 & 0.3 & 0 & 0.3 \\
\hline Mean & $8.77^{\mathrm{a}}$ & $7.3^{b}$ & $8.81^{\mathrm{ab}}$ & $13.31^{\mathrm{ab}}$ & $9.05^{\mathrm{ab}}$ \\
\hline Max & 19.2 & 22.5 & 40.4 & 26.9 & 40.4 \\
\hline \multicolumn{6}{|l|}{ Chalk Impact (0-100) } \\
\hline Min & 0.49 & 0.18 & 0 & 0 & 0 \\
\hline Mean & $3.7^{\mathrm{a}}$ & $3.5^{\mathrm{a}}$ & $6.98^{\mathrm{b}}$ & $15.25^{c}$ & $2.32^{d}$ \\
\hline Max & 10.1 & 27.83 & 85.48 & 85.48 & 15.1 \\
\hline Observations & 101 & 112 & 150 & 54 & 96 \\
\hline 2018 Per Capita & & & & & \\
\hline Rice Consumption (kg) & $29.7^{* *}$ & $31.5^{* * *}$ & $47.8^{* * *}$ & - & - \\
\hline
\end{tabular}




\subsection{Quality Impacts}

\subsubsection{Percentage of Brokens}

We find that in Ghana (both in domestic and imported rice) and Mozambique increased brokens reduce rice price. In Mozambique a 1\% increase in brokens would reduce price by 0.094\% ( $\mathrm{P}<0.01)$ (Table 2). To put this in perspective, the difference between the maximum and minimum percentage of broken rice in the Mozambique rice samples was $21 \%$ (Table 1 ). This difference coupled with the estimated impact of brokens on price would suggest that there would be a price difference of $1.95 \%$, a small difference given any definition. This would suggest that consumers don't care about brokens, and as such vendors don't adjust price for broken quantity. Alternatively, there is a market failure and because consumers can't differentiate between samples with different percentages of brokens, rice vendors take advantage of this. This result could suggest that rice may not be priced according to its percent brokens, considering the Mozambican government stated the grading and standardization system in Mozambique for rice is weak ("Republic of Mozambique", 2009). Further research is warranted in Mozambique to determine if consumers really do not discount broken rice (at a high percentage) or vendors are not pricing rice according to the broken percentage it contains. In the current markets, there appears to be little incentive for the rice supply chain to improve rice quality by reducing broken rice because either consumers are insensitive to percentage broken or the market is not providing a premium. 
Table 2 Impact of Rice Quality Variables on Price

\begin{tabular}{lccccc}
\hline Variable & DRC & Mozambique & $\begin{array}{c}\text { Ghana } \\
\text { (Total) }\end{array}$ & $\begin{array}{c}\text { Ghana } \\
\text { (Domestic) }\end{array}$ & $\begin{array}{c}\text { Ghana } \\
\text { (Imported) }\end{array}$ \\
\hline Constant & $3.023^{* * *}$ & $2.183^{*}$ & -1.249 & -1.565 & -0.810 \\
& {$[1.146]$} & {$[1.158]$} & {$[1.219]$} & {$[2.814]$} & $(1.56)$ \\
Broken & -0.006 & $-0.094^{* * *}$ & $-0.082^{* * *}$ & $-0.136^{*}$ & $-0.075^{* *}$ \\
& {$[0.028]$} & {$[0.034]$} & {$[0.022]$} & {$[0.075]$} & $(0.030)$ \\
Length & $1.362^{* * *}$ & -0.034 & $1.417^{* *}$ & 1.419 & $1.383^{* *}$ \\
& {$[0.420]$} & {$[0.452]$} & {$[0.582]$} & {$[1.321]$} & $(0.623)$ \\
Width & $1.902^{* * *}$ & $2.339^{* * *}$ & 0.590 & 1.072 & 0.116 \\
& {$[0.7111]$} & {$[0.681]$} & {$[0.410]$} & {$[1.167]$} & $(0.853)$ \\
Chalk & $0.049^{* * *}$ & $-0.065^{* *}$ & 0.002 & 0.002 & 0.001 \\
& {$[0.017]$} & {$[0.026]$} & {$[0.001]$} & {$[0.003]$} & $(0.002)$ \\
Parboiled & - & - & $-0.303^{* * *}$ & $-0.280^{* * *}$ & $-0.353^{* *}$ \\
& & & {$[0.076]$} & {$[0.096]$} & $(0.141)$ \\
& & & & & \\
$\mathrm{R}^{2}$ & 0.279 & 0.416 & 0.304 & 0.363 & 0.233 \\
Observations & 101 & 112 & 150 & 96 & 54 \\
\hline
\end{tabular}

$* * *, * * *$ denote $\mathrm{P}<0.01, \mathrm{P}<0.05$ and $\mathrm{P}<0.1$, respectively.

[] denote, robust standard errors, and () represent non-robust standard errors.

A similar story unfolds in Ghana (total sample) where the difference between maximum and minimum percentage of brokens is $40.1 \%$ (Table 1 ) and the estimated coefficient on broken rice is $-0.082(P<0.01)$ resulting in a difference in rice price of only $3.28 \%$. Unlike Mozambique, there is existing literature on Ghanaian consumer preferences and broken rice has been found to be discounted (Demont et al., 2013; Demont and Rizzotto, 2012; Sedem et al., 2017). Our results suggest that vendors are either: (1) not pricing rice according to the percentage broken, or (2) they simply do not know the percentage broken and thus price all visually similar rice equally. Asante (2013) interviewed 206 Ghanaian consumers about rice preference and 20\% and $39 \%$ listed percentage of broken grains as either very important or important, respectively (out of four Likert categories, only $14 \%$ said it was not important). This seems to indicate the 
existence of some market inefficiencies, either from a rent seeking standpoint or simply from the supply chain not preserving the milling information.

The DRC estimates indicate that price was not a function $(P>0.1)$ of broken rice. Like Mozambique this warrants further research on consumer preferences as there has not been a consumer preference study on rice quality attributes in DRC. Our results indicate that either consumers are indifferent to broken rice percentage or markets are simply not pricing rice accordingly. It would seem unlikely that consumers would be indifferent given the high difference in maximum and minimum of brokens in our sample period with the lack of market standards. If consumers were truly indifferent, it would be more profitable for vendors to sell higher amounts of brokens, ceteris paribus, as they cost less to source.

\subsubsection{Grain Chalkiness}

Chalk was not found to affect price $(P>0.1)$ in Ghana for all samples (domestic, imported and the pooled sample). This is an interesting result as Ghana had the highest average and largest standard deviation of chalk (Table 1). Diving deeper however, imported rice in Ghana had the lowest average chalk impact and a lower variance, indicating that given the low amount of chalk in imported rice and the fact that chalk values are consistently low and homogeneous across samples, the variation in chalk is not enough to warrant price changes. Conversely, domestic rice in Ghana had the highest chalk possibly indicating that domestic rice is simply priced as such, where imported rice may have differentiating price impacts (broken and length).

In Mozambique chalk was found to negatively affect rice price, with a $1 \%$ increase in chalk resulting in a 0.065 percent decrease (Table 2$)$ in price $(P<0.05)$. The difference between the chalkiest average sample and the least in Mozambique was $27.65 \%$, which would result in a 
price difference of $1.79 \%$. While seemingly small, it is often difficult for consumers to assess chalkiness. Both chalk definitions (percent chalky and chalkiness) were modeled and chalkiness as we define it produced more robust results, having more statistical power with similar coefficients. Regardless of definition, it appears that chalk, while significant, is either not being priced correctly or is simply not a large factor in rice price in Mozambique.

Chalk in the DRC samples had the lowest variance, lowest maximum and relatively small mean. That being said, chalk was found statistically significant $(P<0.01)$ with a one percent increase in chalk resulting in an increase in price of $0.049 \%$. While this result is counterintuitive the difference between the largest and smallest average chalk sample in DRC was 9.61\% resulting in a price difference of $0.47 \%$ in price. Given the low variance and low mean chalk value it is likely that rice vendors simply cannot visually differentiate the "best" from the "worst" sample with regards to chalk. More research is warranted based on this result to see if vendors would price accordingly when the variance increases.

\subsubsection{Kernel Length and Width}

When the Ghanaian samples are disaggregated, it was found that neither length nor width affected the price of domestic rice, and only length affected the price of imported rice, with longer kernels being priced at a premium (Table 2). One hypothesis on why domestic rice price is not a function of length or width while imported rice price is could be that imported rice is seen as superior to domestic rice and consumers are more selective when purchasing. The difference between the longest and shortest average sample grain length for imported rice in Ghana was $35.85 \%$ (Table 1 ) which would result in a price difference of $49.58(P<0.05)$ percent. 
Interestingly, in Mozambique width was found to affect price with a $1 \%$ increase in width leading to a $2.4 \%$ in price $(P<0.01)$ but price was not found to be a function of length. The difference between the largest average width sample collected in Mozambique and the smallest average width sample was $18.72 \%$. Using the estimated coefficient from Table 2 would result in a price difference of $43.79 \%$, ceteris paribus.

In DRC, it was found that rice price is both a function of length and width with wider and longer kernels being priced at a premium. The difference between the average longest and shortest kernel length samples from DRC was $28.5 \%$ (7.56 and $5.88 \mathrm{~mm}$, respectively). Given this and the length coefficient of $1.362(P<0.01)$ the difference in the price of the above samples is estimated to be $38.8 \%$, ceteris paribus. A similar story is found for the effects of width on rice price in DRC where the difference between the largest and smallest average sample was found to be $12.2 \%$ ( 2.47 and $2.2 \mathrm{~mm}$, respectively), which would result in an estimated price difference of $23.2 \%$, using the width coefficient of $1.902(P<0.01)$.

\subsection{Value Heterogeneity across African Countries}

Having looked at differences between the three countries on an attribute level, we also considered the absolute difference in price on a holistic level for a rice sample sold in each of the three countries. Figure 1 shows the percent difference in price if the average quality of rice in one country was sold in another. The average sample is defined as the mean of the quality attributes from each country. The preferred model for each country, in Table 2, was used to calculate the average log price. The parboiled data in Ghana was not used in the percent difference calculation in DRC and Mozambique. Zero was used as the average of the parboiled quality attribute for DRC and Mozambique in Ghana. Considering most of the rice imported to 
DRC, Mozambique, and Ghana is of similar quality (Table 1), the statistical difference in price can largely be attributed to difference in preferences in each country. This highlights how rice is not a homogeneous commodity in that countries value the same sample differently. We should note these differences in price do not include any transportations costs. Therefore the difference in price should not be viewed as an opportunity for arbitrage, but instead as an illustration of the contribution of each quality attribute to the price in different markets.

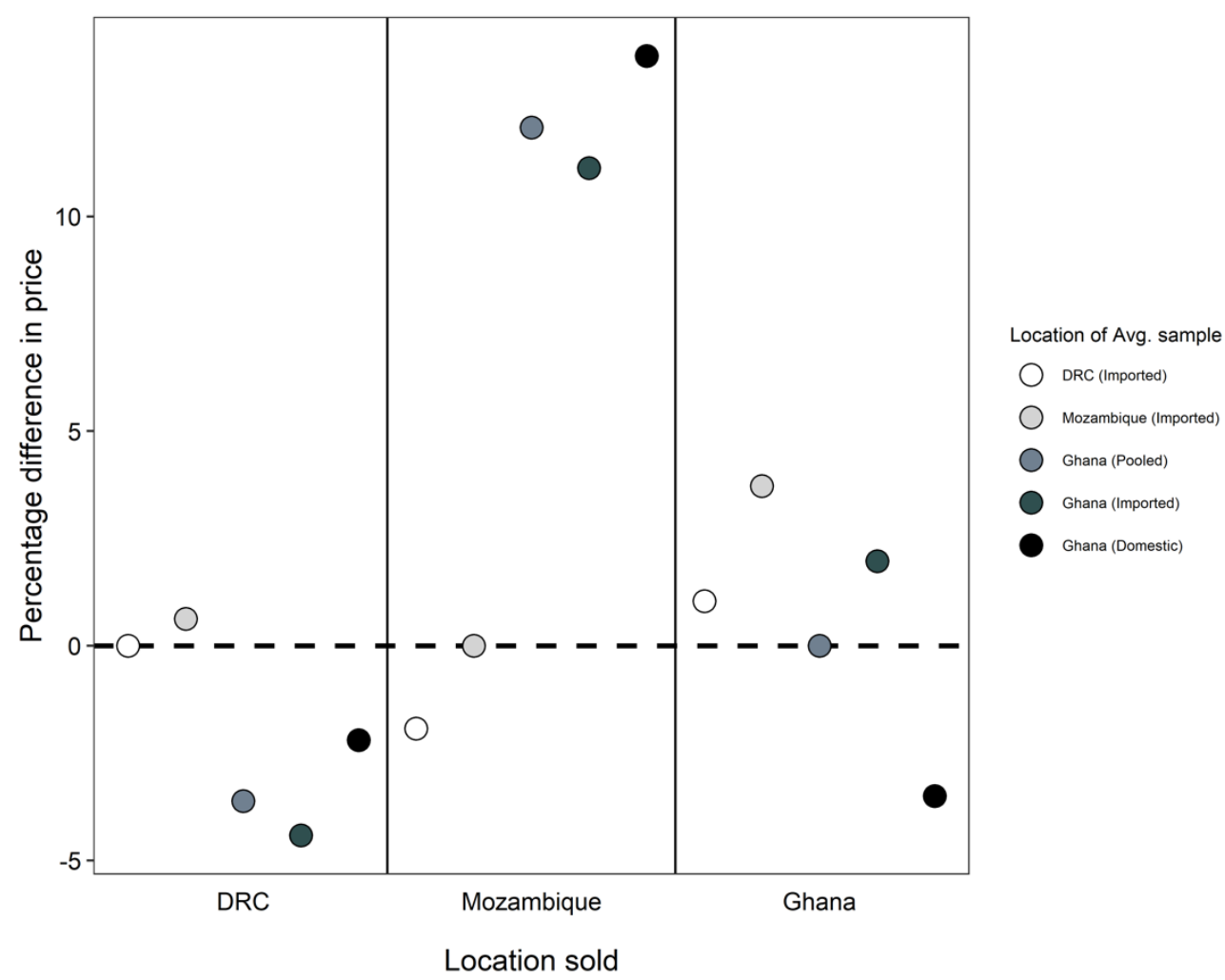

Figure 1 Percentage Difference in Value of Average Quality Rice Sold in Alternative Countries.

\subsubsection{Democratic Republic of the Congo}

In DRC, the average sample of Mozambique rice would be valued $0.63 \%$ higher than the average sample of DRC rice. The rice from Mozambique has higher average length and width than the rice from DRC, so the higher valuation is congruent with the previously discussed 
results. The average of all rice, domestic and imported, from Ghana is valued $3.62 \%$ less than average DRC rice in a DRC market. The average of rice imported to Ghana is valued at $4.42 \%$ less than the average sample of DRC rice. While the average sample of domestic Ghanaian rice is valued at $2.2 \%$ less than the DRC average sample. In DRC, domestic Ghanaian rice would be valued higher than rice imported to Ghana. The domestic rice grown in Ghana is on average longer and wider than the imported rice with higher levels of chalkiness and brokens. Because brokens and chalkiness are not heavily discounted in DRC, the preference for Ghana's domestic rice confirms our previous results.

\subsubsection{Mozambique}

In Mozambique, the average sample of rice from DRC would be worth $1.93 \%$ less than the average sample of rice from Mozambique. DRC rice is valued lower than the Mozambican rice in Mozambique for the same reason Mozambican rice was valued higher in DRC. Both countries have similar levels of chalkiness while Mozambique has the higher average width of rice kernels. The average sample of all rice from Ghana would be worth $12.07 \%$ more than the average sample of Mozambican rice. The average rice sample imported to Ghana would be worth $11.13 \%$ more than the average of Mozambican rice. The average sample of domestic Ghanaian rice would be worth $13.74 \%$ more than the average Mozambican rice sample sold in Mozambique. Again, the domestic rice from Ghana is valued higher than rice that is imported to Ghana.

\subsubsection{Ghana}

For Ghana the baseline is the average sample of all rice in Ghana, including both domestic and imported rice. The average sample of DRC rice sold in Ghana would be worth 
$1.04 \%$ more than average sample of Ghanaian rice. The average Mozambican sample of rice would be worth $5.92 \%$ more than the average sample of total rice in Ghana. The average sample of rice imported to Ghana would be worth $2.19 \%$ more than the average sample of total rice in Ghana. Compared to the average domestic rice sample which is valued at $3.89 \%$ less than the average sample of total rice in Ghana. In contrast with DRC and Mozambique, the rice imported into Ghana is valued higher than domestic rice. Among the three countries involved in this study, the preference for the rice imported to Ghana over domestic Ghanaian rice, when considering the average sample, is unique to Ghana but congruent with previous findings.

Although parboiled rice is a value-added attribute, it was found to decrease price for both imported $(P<0.01)$ and domestic $(P<0.05)$ rice. Results from Table 2 indicate that, ceteris paribus, domestic parboiled rice sells for $28 \%$ less than non-parboiled and imported parboiled sells for $35.3 \%$ less than non-parboiled imported rice. These results are consistent with previous literature (Taylor and Archibald, 2019; Tomlins et al., 2005) on Ghanaian consumer demand where it was found that although consumers perceived parboiled rice to have higher nutritional qualities (and thus often preferred by local governments), it is less preferred by most consumers due to perceived poor quality of domestic parboiled rice.

For every specification, the directional fixed effect for Ghanaian markets was insignificant (Table 3). The robust insignificance, across seven model specifications, would seem to indicate that the region of purchase in Ghana does not significantly influence price. 
Table 3 Ghanaian Locational (Accra and Outside of Accra) Models

\begin{tabular}{|c|c|c|c|c|c|c|c|}
\hline Variable & $(1)$ & $(2)$ & (3) & (4) & (5) & (6) & (7) \\
\hline Constant & $\begin{array}{c}-2.426 * * \\
{[1.200]}\end{array}$ & $\begin{array}{c}-2.828 * * \\
{[1.192]}\end{array}$ & $\begin{array}{l}\mathbf{- 1 . 2 8 6} \\
{[1.210]}\end{array}$ & $\begin{array}{c}1.824 * * * \\
{[0.371]}\end{array}$ & $\begin{array}{c}1.884 * * * \\
{[0.371]}\end{array}$ & $\begin{array}{l}-1.261 \\
{[1.223]}\end{array}$ & $\begin{array}{c}-1.366 \\
{[1.238]}\end{array}$ \\
\hline Broken & - & - & $\begin{array}{c}-0.078 * * * \\
{[0.022]}\end{array}$ & $\begin{array}{c}-0.109 * * * \\
{[0.022]}\end{array}$ & $\begin{array}{c}-0.099 * * * \\
{[0.025]}\end{array}$ & $\begin{array}{c}-0.073^{* * *} \\
{[0.025]}\end{array}$ & $\begin{array}{c}-0.080 * * * \\
{[0.022]}\end{array}$ \\
\hline Length & $\begin{array}{c}1.799 * * * \\
{[0.596]}\end{array}$ & $\begin{array}{c}2.057 * * * \\
{[0.585]}\end{array}$ & $\begin{array}{c}1.365 * * \\
{[0.574]}\end{array}$ & - & - & $\begin{array}{c}1.336 * * \\
{[0.588]}\end{array}$ & $\begin{array}{c}1.446 * * \\
{[0.588]}\end{array}$ \\
\hline Width & $\begin{array}{l}\text { 0.758* } \\
{[0.400]}\end{array}$ & $\begin{array}{l}0.670^{*} \\
{[0.403]}\end{array}$ & $\begin{array}{c}\mathbf{0 . 6 3 5} \\
{[0.410]}\end{array}$ & - & - & $\begin{array}{c}\mathbf{0 . 6 5 1} \\
{[0.415]}\end{array}$ & $\begin{array}{c}\mathbf{0 . 5 6 1} \\
{[0.410]}\end{array}$ \\
\hline $\begin{array}{l}\text { Length to } \\
\text { Width ratio }\end{array}$ & - & - & - & $\begin{array}{c}\mathbf{0 . 0 6 0} \\
{[0.153]}\end{array}$ & $\begin{array}{c}\mathbf{0 . 0 1 7} \\
{[0.157]}\end{array}$ & - & - \\
\hline $\begin{array}{l}\text { Chalk } \\
\text { impact }\end{array}$ & - & $\begin{array}{c}\mathbf{0 . 0 0 1} \\
{[0.001]}\end{array}$ & - & $\begin{array}{c}0.001 \\
{[0.002]}\end{array}$ & - & - & $\begin{array}{c}0.002 \\
{[0.001]}\end{array}$ \\
\hline Chalky (\%) & $\begin{array}{c}-\mathbf{0 . 0 0 1} \\
{[0.001]}\end{array}$ & - & - & - & $\begin{array}{l}-0.0005 \\
{[0.001]}\end{array}$ & $\begin{array}{c}-0.0004 \\
{[0.001]}\end{array}$ & - \\
\hline Parboiled & $\begin{array}{c}-0.314^{* * *} \\
{[0.068]}\end{array}$ & $\begin{array}{c}-0.243 * * * \\
{[0.074]}\end{array}$ & $\begin{array}{c}-0.340 * * * \\
{[0.067]}\end{array}$ & $\begin{array}{c}-0.297^{* * *} \\
{[0.077]}\end{array}$ & $\begin{array}{c}-0.345 * * * \\
{[0.072]}\end{array}$ & $\begin{array}{c}-0.349 * * * \\
{[0.070]}\end{array}$ & $\begin{array}{c}-0.299 * * * \\
{[0.077]}\end{array}$ \\
\hline Accra & $\begin{array}{c}\mathbf{0 . 1 2 7} \\
{[0.087]}\end{array}$ & $\begin{array}{c}0.127 \\
{[0.099]}\end{array}$ & $\begin{array}{c}0.095 \\
{[0.065]}\end{array}$ & $\begin{array}{c}\mathbf{0 . 0 7 1} \\
{[0.086]}\end{array}$ & $\begin{array}{c}0.080 \\
{[0.088]}\end{array}$ & $\begin{array}{c}0.095 \\
{[0.066]}\end{array}$ & $\begin{array}{c}\mathbf{0 . 0 8 5} \\
{[0.067]}\end{array}$ \\
\hline $\mathrm{R}^{2}$ & 0.262 & 0.257 & 0.296 & 0.260 & 0.255 & 0.298 & 0.307 \\
\hline Observations & 150 & 150 & 150 & 150 & 150 & 150 & 150 \\
\hline
\end{tabular}

\section{Discussion}

Rice is an important staple food globally and is increasingly important across Sub-

Saharan Africa. Functioning markets and pricing of commodities are key tools for promoting

food security for the most vulnerable populations. Our study provides critical insights into how

quality affects rice prices in DRC, Mozambique and Ghana as well as revealed areas for future

analysis. One of the main findings of this study is that each country seems to have distinctive 
pricing differences for quality attributes. Even if countries price certain quality attributes positively the magnitude can be drastically different. This highlights the fact that rice price can vary greatly based on small quality differences and should be priced based on specific quality attributes. The results of broken rice impacts on prices are thought-provoking because they demonstrate the likelihood of market failures in Ghana, and simultaneously generate deeper questions about consumer preferences in Mozambique and DRC. There is extensive, nonhypothetical literature on Ghanaian consumer preference for non-broken rice yet there the estimated discount for brokenness is minimal. Our study would seem to suggest that vendors in Ghana are not pricing rice based on these stated preferences. The range of percent brokens in Ghanaian samples (40.1\%) and the estimated small impact (3.28\%) suggests one of two market failures.

First, vendors simply may not be aware of the percentage of brokens in the rice they are selling. While initial importers would have to be aware of this percentage because they pay exporters based on this, the supply chain may be breaking down prior to the final sale to consumers. This could be due to mixing of open bags or mixing of different rice types. The second potential market failure may be the fact that vendors are aware of broken percentages but are aware that consumers cannot visually assess differences and thus do not discount rice prices accordingly. Regardless of the type of market failure illustrated in our results (reinforced by previous literature on Ghanaian rice preferences), the findings indicate a compelling need for increased grading and standards at the final point of sale. Further segmentation of rice by percent broken could increase total welfare, if consumer welfare increases more than vendor welfare decreases, and specifically improve the purchasing ability of lower income people. Still, 
it should be noted that the cost of implementing regulated standards could lead to increased price of all rice, regardless of quality. Even if regulated standards reduce the price of low quality rice, the cost of implementation and monitoring could again increase the price of the low quality rice leading to ambiguous impacts on welfare. In the case of inefficient markets, standards should be introduced with continual monitoring to avoid unintended decreases in welfare among the low-income group. Further research is warranted to see if consumer WTP would warrant standards for open bag rice markets and what, if any, of the additional regulation costs would be split between consumers and vendors. Future research is also needed to help understand these results better, such as conducting consumer preference studies that would allow for comparison of the pricing behavior by vendors with what consumers' revealed preferences for selected rice quality attributes are.

We provide a first empirical examination of rice price response to quality attributes, finding relatively small impacts of brokens on rice price. Given the fact that the Mozambican government stated the grading and standardization system in Mozambique for rice is weak, and is yet to become an important tool for both domestic [rice] production and consumption, one of two things become apparent. Our results indicate either consumers do not value whole rice and are not willing-to-pay a premium (we find a premium but it's not a large factor), or the lack of standards and grading has led to a market failure. Given the large range of broken rice in the Mozambican sample (21 percent) and its small estimated impact, our results would at the least suggest a market failure in labeling and pricing to some degree. If consumers did not care about broken rice, then the mean of all samples should be higher than $3.5 \%$, which is low by international standards as broken rice is sustainably cheaper to purchase on the international 
market. In a relative context, Lyman et al. (2013) found that broken rice is priced at $40 \%$ below head rice (whole kernels) and as such we should see a 9.2\% (40 percent multiplied by 21 percent) difference between the max and the min brokens in Mozambique.

One potential argument for the small, relative price differences amongst quality attributes is that consumers cannot visually differentiate marginal differences (say the difference between 15 and 25 percent brokens). One explanation is simply that consumers don't demand higher quality rice and that sellers thus do not take these characteristics into pricing. That being said, all the quality attributes in this study directly affect the cooking and texture of rice once prepared. Thus, another possible scenario is that consumers can't visually differentiate marginal differences in quality but value them after preparation is complete. All this being said, if consumers truly did not value quality attributes such as broken and chalky rice we should have seen a much higher volume of broken and chalky rice in the samples since rice vendors can source this much cheaper on the international market. This would seem to imply that consumers do value these quality attributes but have a difficult time delineating them in an open bag setting.

The results of this study are important on two distinct fronts. First, because the rice culture (preferences) is not embedded in the fabric of most African countries (unlike Asia), market preferences are still developing. In some countries, such as Nigeria, rice traders/importers have proactively set high barriers to entry for rice quality which results in the urban middle and high classes to benefit from rice imports while the poor are priced out of the market (Lancon and Benz, 2007). Other countries, such as the DRC, Mozambique and Ghana, do not have quality import regulations yet and as such, consumers and not policymakers are 
driving the market prices and their regulations (or lack of quality regulations). The potential for indifference, based on insignificance in DRC and minimal price discount in Mozambique, to brokens in Mozambique and DRC has important food security and importation implications. Since many countries where rice is embedded into their culture discount broken rice, there is often an excess supply of broken rice which leads it to be used in the pet food or brewing industries. If more markets accept broken (or at least a higher percentage of broken) rice, then a possibility exists to increase food security and input-use efficiency in a food security context (as rice uses a high volume of water). The results of this study can be used by rice importers and exporters who are trying to best segment the rice market in DRC, Mozambique and Ghana, and perhaps more broadly throughout Sub-Saharan Africa. Most importantly, this study should be used as a spring board for future research focused on the potential of rice importers/exporters to segment rice with high percentage of brokens when serving the DRC and Mozambican markets. From a food security perspective, future research should use non-hypothetical experiments to determine what, if any, thresholds consumers would value for broken rice in Mozambique and DRC, two of Africa's fastest growing countries. 


\section{References}

Alhassan, H., Frimpong, T. and Mohammed, A.S. (2016), "DO GHANAIAN RURAL CONSUMERS PREFER IMPORTED RICE TO LOCAL RICE?”, Applied Research Journal, Vol. 1 No. 3, (accessed 2 July 2020).

Asante, D. (2013), "Farmer and consumer preferences for rice in the Ashanti region of Ghana: Implications for rice breeding in West Africa", Journal of Plant Breeding and Crop Science, Vol. 5 No. 12, pp. 229-238.

Ayeduvor, S. (2018), Assessing Quality Attributes That Drive Preference and Consumption of Local Rice in Ghana, No. 48, GSSP Working Papers, International Food Policy Research Institute (IFPRI), available at: https://ideas.repec.org/p/fpr/gsspwp/48.html (accessed 30 October 2020).

Calingacion, M., Laborte, A., Nelson, A., Resurreccion, A., Concepcion, J.C., Daygon, V.D., Mumm, R., et al. (2014), "Diversity of Global Rice Markets and the Science Required for Consumer-Targeted Rice Breeding", edited by Yan, W.PLoS ONE, Vol. 9 No. 1, p. e85106.

Cuevas, R.P., Pede, V.O., McKinley, J., Velarde, O. and Demont, M. (2016), "Rice Grain Quality and Consumer Preferences: A Case Study of Two Rural Towns in the Philippines", edited by Yang, D.PLOS ONE, Vol. 11 No. 3, p. e0150345.

Demont, M. and Ndour, M. (2015), "Upgrading rice value chains: Experimental evidence from 11 African markets", Global Food Security, Vol. 5, pp. 70-76.

Demont, M., Ndour, M. and Zossou, E. (2013), “Can local African rice be competitive? An analysis of quality-based competitiveness through experimental auctions", Cahiers Agricultures, Vol. 22 No. 5, pp. 345-352.

Demont, M. and Rizzotto, A.C. (2012), "Policy Sequencing and the Development of Rice Value Chains in Senegal", Development Policy Review, Vol. 30 No. 4, pp. 451-472.

Durand-Morat, A. and Chavez, E.C. (n.d.). "International Rice Outlook International Rice Baseline Projections, 2019-2029”, p. 124.

Dobermann, A. (2012). "IRRI agronomy challenge: Another tricky choice... water management", available at: http://irri.org/blogs/achim-dobermann-s-blog/irriagronomy-challengeanother-tricky-choice-water-management

"FAOSTAT". (n.d.). , available at: http://www.fao.org/faostat/en/\#country/250 (accessed 16 December 2020).

Fitzgerald, M.A. and Resurreccion, A.P. (2009), "Maintaining the yield of edible rice in a warming world", Functional Plant Biology, Vol. 36 No. 12, p. 1037.

Gariboldi, F. (1974), Rice Parboiling, Rome: Food and Agriculture Organization of the United Nations. 
Grassi, C., Bouman, B.A.M., Castañeda, A.R., Manzelli, M. and Vecchio, V. (2009), "Aerobic rice: crop performance and water use efficiency", Journal of Agriculture and Environment for International Development, Vol. 103 No. 4, available at:https://doi.org/10.12895/jaeid.20094.35.

Helgi Library. (n.d.). "Rice Consumption Per Capita in Congo", available at: https://www.helgilibrary.com/indicators/rice-consumption-per-capita/congo (accessed 2 July 2020).

Ines, R. and Wade, P. (2016), The State of Food Insecurity in Maputo, Mozambique, Southern African Migration Programme.

Khush, G.S., Paule, C.M. and De La Cruz, N. (1978), "Rice grain quality evaluation and improvement at IRRI Los Banos", International Rice Research Institute, pp. 22-31.

Kihoro, J., Bosco, N.J. and Murage, H. (2013), "Suitability analysis for rice growing sites using a multicriteria evaluation and GIS approach in great Mwea region, Kenya", SpringerPlus, Vol. 2 No. 1, p. 265.

Lancaster, K. (1971), Consumer Demand: A New Approach., Columbia University Press, New York.

Lancon, F. and Benz, H.D. (2007), "Rice imports in West Africa: trade regime and food policy formulation.", AgEcon Search, available at: https://doi.org/10.22004/ag.econ.7906.

Lanning, S.B., Siebenmorgen, T.J., Counce, P.A., Ambardekar, A.A. and Mauromoustakos, A. (2011), "Extreme nighttime air temperatures in 2010 impact rice chalkiness and milling quality", Field Crops Research, Vol. 124 No. 1, pp. 132-136.

Long, J.S. and Ervin, L.H. (2000), "Using Heteroscedasticity Consistent Standard Errors in the Linear Regression Model", The American Statistician, Taylor \& Francis, Vol. 54 No. 3, pp. 217-224.

Lusk, J. and Shogren, J.F. (2007), Experimental Auctions: Methods and Applications in Economic and Marketing Research, Cambridge University Press, Cambridge ; New York.

Lyman, N.B., Jagadish, K.S.V., Nalley, L.L., Dixon, B.L. and Siebenmorgen, T. (2013), “Neglecting Rice Milling Yield and Quality Underestimates Economic Losses from High-Temperature Stress", edited by Nelson, J.C.PLoS ONE, Vol. 8 No. 8, p. e72157.

Mekonnen, M.M. and Hoekstra, A.Y. (2016), "Four billion people facing severe water scarcity", Science Advances, Vol. 2 No. 2, p. e1500323.

Muthayya, S., Sugimoto, J.D., Montgomery, S. and Maberly, G.F. (2014), “An overview of global rice production, supply, trade, and consumption: Global rice production, consumption, and trade", Annals of the New York Academy of Sciences, Vol. 1324 No. 1, pp. 7-14.

Nasrin, S., Bergman Lodin, J., Jirström, M., Holmquist, B., Andersson Djurfeldt, A. and Djurfeldt, G. (2015), "Drivers of rice production: evidence from five Sub-Saharan African countries", Agriculture \& Food Security, Vol. 4 No. 1, p. 12. 
"Next Instruments :: SeedCount". (n.d.). , available at:

https://www.nextinstruments.net/products/seedcount (accessed 30 October 2020).

"Population growth (annual \%) - Sub-Saharan Africa, Sub-Saharan Africa (excluding high income) | Data". (n.d.). The World Bank, available at:

https://data.worldbank.org/indicator/SP.POP.GROW?locations=ZG-

ZF\&most_recent_value_desc=true (accessed 2 July 2020).

"Production, Supply and Distribution Online (PS\&D)". (n.d.). United States Department of Agriculture Foreign Agricultural Services, available at:

https://www.fas.usda.gov/databases/production-supply-and-distribution-online-psd.

Rice: Global Competitiveness of the U.S. Industry. (2015), , United States International Trade Commission, pp. 346-347.

Sedem Ehiakpor, D., Apumbora, J., Danso-Abbeam, G. and Adzawla, W. (2017), "Households' Preference for Local Rice in the Upper East Region, Ghana", Advances in Agriculture, Vol. 2017, pp. 1-9.

Singh, N., Sodhi, N.S., Kaur, M. and Saxena, S.K. (2003), "Physico-chemical, morphological, thermal, cooking and textural properties of chalky and translucent rice kernels", Food Chemistry, Vol. 82 No. 3, pp. 433-439.

Taylor, J. and Archibald, D. (2019), Ghana, Grain and Feed Annual Report.

Tomlins, K.I., Manful, J.T., Larwer, P. and Hammond, L. (2005), “Urban consumer preferences and sensory evaluation of locally produced and imported rice in West Africa", Food Quality and Preference, Vol. 16 No. 1, pp. 79-89.

"Towards Implementation of National Rice Development Strategies in Mozambique". (2009), , Ministry of Agriculture, Republic of Mozambique, available at: https://riceforafrica.net/downloads/Countries/mozambique/Moz_PromoMaterial.pdf.

Tuong, P., Bouman, B.A.M. and Mortimer, M. (2005), "More Rice, Less Water-Integrated Approaches for Increasing Water Productivity in Irrigated Rice-Based Systems in Asia", Plant Production Science, Taylor \& Francis, Vol. 8 No. 3, pp. 231-241.

United Nations. (2003). UN comtrade.

Wang, Y.-J., Wang, L., Stephard, D., Wang, F. and Patindol, J. (2002), "Properties and Structures of Flours and Starches from Whole, Broken, and Yellowed Rice Kernels in a Model Study", Cereal Chemistry, Vol. 79, p. 383.

"World Economic Outlook Database October 2019". (n.d.). International Monetary Fund, available at: https://www.imf.org/external/pubs/ft/weo/2019/02/weodata/index.aspx (accessed 2 July 2020).

Zeileis, A. (2004), "Econometric Computing with HC and HAC Covariance Matrix Estimators", Journal of Statistical Software, Vol. 11 No. 10, available at:https://doi.org/10.18637/jss.v011.i10. 
Zeileis, A. and Hothorn, T. (2002), "Diagnostic Checking in Regression Relationships", R News, Vol. 2 No. 3, pp. 7-10. 


\section{Appendix}

\subsection{Rice Quality}

Rice is distinct from other row crops because it is a field-to-plate crop, meaning the product eaten by consumers is typically the full rice kernel rather than a processed product, like flour (unlike maize, wheat and soybeans, which are typically more heavily processed). So, in rice, quality, specifically appearance, is of importance to consumers. The remainder of this section will describe the visually quality traits we consider in this study beginning with rice brokenness then moving to rice chalkiness and finishing with kernel length and width.

\subsubsection{Broken Rice}

After the hull and bran have been removed, the resulting mass is milled rice, which is then separated into brokens and head rice. As an illustrative example, if $100 \mathrm{~kg}$ of clean rice were delivered to a mill, the rough/paddy rice would be processed to remove the hull, and bran. Because the hull, and bran have mass, the resulting mass of rice would be $<100 \mathrm{~kg}$. In the United States (U.S.) the rice futures market is traded on an average of $70 \%$ milled rice, so the milled rice yield (MRY) would be $70 \mathrm{~kg}$ for this example. Of this $70 \mathrm{~kg}$ of remaining mass, some kernels would stay intact and some would break during the milling process. In the U.S., the rice futures market is traded assuming that $55 \%$ of the initial mass is whole kernels (HRY). Thus, in this example, there would be $55 \mathrm{~kg}$ of head rice for a HRY of 55\%. The difference between MRY and HRY is the percentage of the initial mass that are broken kernels. Thus, $15 \%$ (in this case 15 $\mathrm{kg}$ ) would be broken rice (70\%-55\%). In the United States rice is traded at a benchmark of $15 \%$ brokens. In some countries, (oddly enough, mostly low-income) like Haiti and Nigeria the imported broken percentage is under five percent. It is likely that consumers in Haiti would 
consume rice with over five percent brokens but it is not allowed to be imported. In Nigeria, despite a documented preference for imported rice, the extreme tariffs, as high as $110 \%$, can prevent the consumption of the preferred imported rice ("US International Trade Commission", 2015; Lancon and Benz, 2007). Importantly, it is worth noting that brokens are a function of genetics, growing environment, and milling technology, eliminating or reducing broken rice is a difficult process for rice breeders and millers.

In U.S. rice production some brokens are exported, most are used domestically, in the form of flour, or in pet foods for a lower value because of strict quality standards set by importing countries. In the U.S., brokens are valued at $60 \%$ of the value of whole kernels and are valued lower than that in many Asian countries (Lyman et al., 2013). Selling rice for a lower value domestically and diverting food intended for human consumption to animal consumption, creates welfare losses when other export markets exist that could be indifferent to visual qualities, specifically low-income countries. Market failures could exist in countries where there are strict import quality standards if consumers in those countries would be willing-to-pay for lower quality rice. This is especially true in low-income countries where the poorest of the poor maybe able to enter the rice market if its quality attributes are appropriately segregated and labeled.

\subsubsection{Chalky Rice}

Visual characteristics of rice grains are important search attributes that affect consumers' purchasing decisions, specifically in open bag settings, and are used as some of the first selection criteria in rice breeding programs (Cuevas et al., 2016). Chalky areas in rice grains, the opaque white parts of the grains, are deemed, generally, to represent poor quality in many 
rice market segments and thus can result in lower prices and demand (Fitzgerald and Resurreccion, 2009). Chalky areas in rice grains are caused by loose packing or incomplete filling of starch granules (Singh et al., 2003). The presence of chalk weakens the grain, leading to elevated incidence of breakage during the milling process and ultimately to reduced head rice yield, thus increased brokens. Like broken rice, chalk is a difficult attribute for breeders to eliminate as it's a function of the genotype, the environment (specifically, hot nights (Lyman et al., 2013; Lanning et al., 2010)) and genotype by environment interactions.

\subsubsection{Rice Length and Width}

Based on its length, rice is commonly classified as short $(<5.5 \mathrm{~mm})$, medium $(5.51-6.6 \mathrm{~mm})$, long (6.61-7.5 mm) and extra-long (>7.51 mm) (Khush et al., 1978), while other standards, such as the international CODEX and the European Union classify a kernel of $6 \mathrm{~mm}$. or more as long grain (Commission, 2003). Rice is commonly classified by grain shape (length/width) into bold (<2), medium (2 - 3), and slender (>3) (Calingacion et al., 2014). Grain length and shape (length/width) are intrinsic attributes valued differently by consumers across markets. For instance, consumers in parts of South East Asia such as Thailand, Lao PDR, Cambodia, Malaysia, and Philippines prefer long and slender grains, while consumers in Indonesia and Bangladesh prefer medium and slender rice. Consumers in North Asia (Japan, South Korea, Northern China, and Taiwan) prefer short and bold rice, whereas extra-long grain is preferred among consumers in Pakistan and Northwestern India (Calingacion et al.,2014).

Most countries have specifications for rice commercialization and trade that explicitly or implicitly include requirements about length and shape. For example, Iraq, the 9th largest importer of rice with an average of 1.1 million metric tons annually in the last 5 years, explicitly 
requires a minimum average kernel length of $6.6 \mathrm{~mm}$ before cooking ("PS\&D", 2020). The standard for milled rice in the East African Community, which includes Burundi, Kenya, Rwanda, South Sudan, Tanzania, and Uganda, classifies rice into long grain, medium grain, short grain, and mixes following international significant standards such as CODEX.

\subsection{Rice in Africa}

By studying three different countries, this study hopes to examine rice markets in different contexts. This section describes the current rice market and previously documented rice preferences for DRC, Mozambique, and Ghana.

\subsubsection{The Democratic Republic of the Congo}

The DRC remains among the poorest countries in the world, ranking 186 out of 192 reporting countries using GDP per capita (PPP) in 2018 according to the International Monetary Fund ("IMF", 2020). From 1999 to 2019 rice consumption increased from 211,000 MT to 402,000 MT (“FAOSTAT", 2020). During that time the $90 \%$ increase in rice consumption outpaced population growth, which grew $83 \%$, indicating rice consumption per capita increased (“FAOSTAT", 2020). Rice imports increased from 1,000 MT to 150,000 MT over the same time period ("FAOSTAT", 2020). In 2018, DRC had the fourth highest annual population growth rate, at 3.25\% in Sub-Saharan Africa ("World Bank", 2020). To our knowledge, no one has examined consumer preference in the DRC, a country without quality import limitations. The government of DRC began the process of writing their National Rice Development Strategy (NRDS) in 2019 and is still working on a final framework. Studies like this can provide important information to that process. 


\subsubsection{Mozambique}

While a poor nation, annual per capita rice consumption in Mozambique more than doubled from $8 \mathrm{~kg}$ in 2000 to $21 \mathrm{~kg}$ in 2007 and increased to $32 \mathrm{~kg}$ in 2020 (Ines and Wase, 2016; Alhassan et al., 2016). Mozambique is a relatively large producer of rice but $90 \%$ of production is for home consumption with only $10 \%$ being marketed. Given this and the fact that Mozambique is a coastal country with several deep-water ports, imported rice dominates local markets. Like DRC, Mozambique has a large population growth rate, $2.9 \%$ annually, the sixth highest in sub-Saharan Africa ("World Bank", 2020).

The 2009 National Rice Development Strategy from the government of Mozambique is one of the few studies that mention consumer preference for rice in Mozambique. The study states that preferences include; medium to long grain; translucent (a proxy for non-chalky), intermediate amylase, non-sticky, with no ordering of preferences given. The same report also states, "Recognized to be internally weak, the grades and standards system in Mozambique is yet to become an important tool for both domestic [rice] production and consumption." Given the Mozambican governments own admission that standards and grading are weak for rice marketing, studies like this are important to see if pricing of rice is affected by these lack of standards.

\subsubsection{Ghana}

Rice consumption in Ghana has quadrupled over the last 60 years with the majority of this increased demand met via imports from Vietnam, China, Thailand and the U.S. Domestic. Ghanaian rice has struggled to compete with imported rice largely due to the perceived low quality of domestic rice by consumers (Ayeduvor, 2018). Alhassan et al. (2016) found that 
Ghanaian consumers reported the physical appearance of rice, when it is sold, as the most important purchasing attribute affecting consumer-purchasing behavior. Similarly, Singh Ehiakpor et al. (Singh et al., 2003) found that the three most important attributes that Ghanaian consumers look for when purchasing rice are search attributes; good looking grains, how clean the rice looks and packaging. The authors found that the credence attributes of taste and texture were fourth and fifth, respectively. These studies show that in Ghana the physical appearance of rice and other search attributes largely drive rice purchases. This should not be a surprise given the predominance of the open bag marketing system in Ghana, consumers look for which rice "appears" the best.

Demont et al. (2013) argued that urban consumers in coastal countries, like Ghana, are typically more susceptible to developing food preference biased towards imported rice. Many West African countries, led by Nigeria but including Ghana, are making a concerted effort to increase domestic production. One large issue is that if production increases but processing infrastructure are not able to ensure minimal quality standards (specifically the percentage of brokens), increased production volumes will quickly saturate local markets and erode domestic prices (Demont et al., 2013; Demont and Rizzotto, 2012). In a study of 11 African rice markets, Demont and Ndour (2015) found that that domestic rice could compete with imported rice in urban markets if its intrinsic and extrinsic quality attributes are better tailored to urban consumer preferences.

Unlike in DRC and Mozambique, parboiled rice is prevalent across Ghana. Parboiling is a steam treatment of paddy rice that alleviates the effects of poor drying (fissuring of the kernel) and improves some aspects of search variables in rice as it reduces the proportion of broken 
kernels. Parboiling can be associated with some visual and taste disadvantages, as it is more yellow in color and has a stronger flavor than non-parboiled rice (Gariboldi, 1974). Tomlins et al. (2005) found that local parboiled rice in Ghana is of relatively poor quality and Ghanaian consumers preferred imported rice and local non-parboiled rice to parboiled rice. Many West African governments promote parboiled rice because it can improve locally produced grain quality (through reduced broken percentage) and the parboiling process increases the watersoluble vitamins and minerals in the rice kernel. 
6.3 Models by Country

Appendix Table 1 Democratic Republic of the Congo Models

\begin{tabular}{|c|c|c|c|c|c|c|c|}
\hline Variable & $(1)$ & $(2)$ & (3) & $(4)$ & $(5)$ & (6) & $(7)$ \\
\hline Constant & $\begin{array}{c}3.215 * * \\
{[1.231]}\end{array}$ & $\begin{array}{c}2.994 * * * \\
{[1.076]}\end{array}$ & $\begin{array}{c}2.890 * * * \\
{[0.830]}\end{array}$ & $\begin{array}{c}6.942 * * * \\
(0.405)\end{array}$ & $\begin{array}{c}\text { 7.035*** } \\
{[0.405]}\end{array}$ & $\begin{array}{c}3.217 * * \\
{[1.277]}\end{array}$ & $\begin{array}{c}3.023 * * * \\
{[1.146]}\end{array}$ \\
\hline Broken & - & - & $\begin{array}{l}-0.005 \\
{[0.031]}\end{array}$ & $\begin{array}{c}-0.014 \\
(0.034)\end{array}$ & $\begin{array}{c}-0.022 \\
{[0.034]}\end{array}$ & $\begin{array}{c}-0.0005 \\
{[0.035]}\end{array}$ & $\begin{array}{c}-0.006 \\
{[0.028]}\end{array}$ \\
\hline Length & $\begin{array}{c}1.363 * * * \\
{[0.428]}\end{array}$ & $\begin{array}{c}1.375^{* * *} \\
{[0.392]}\end{array}$ & $\begin{array}{c}1.427 * * * \\
{[0.303]}\end{array}$ & - & - & $\begin{array}{c}1.362 * * * \\
{[0.453]}\end{array}$ & $\begin{array}{c}1.362 * * * \\
{[0.420]}\end{array}$ \\
\hline Width & $\begin{array}{c}1.715 * * \\
{[0.817]}\end{array}$ & $\begin{array}{c}1.891 * * * \\
{[0.716]}\end{array}$ & $\begin{array}{c}1.977 * * * \\
{[0.588]}\end{array}$ & - & - & $\begin{array}{c}1.716 * * \\
{[0.819]}\end{array}$ & $\begin{array}{c}1.902 * * * \\
{[0.711]}\end{array}$ \\
\hline $\begin{array}{l}\text { Length to } \\
\text { Width ratio }\end{array}$ & - & - & - & $\begin{array}{c}0.147 \\
(0.163)\end{array}$ & $\begin{array}{c}0.089 \\
{[0.164]}\end{array}$ & - & - \\
\hline $\begin{array}{l}\text { Chalk } \\
\text { impact }\end{array}$ & - & $\begin{array}{c}\mathbf{0 . 0 4 9} * * * \\
{[0.017]}\end{array}$ & - & - & $\begin{array}{c}0.059 * * \\
{[0.023]}\end{array}$ & - & $\begin{array}{c}0.049 * * * \\
{[0.017]}\end{array}$ \\
\hline Chalky (\%) & $\begin{array}{c}-0.002 \\
{[0.002]}\end{array}$ & - & - & $\begin{array}{c}-0.002^{* * *} \\
(0.001)\end{array}$ & - & $\begin{array}{l}-0.002 \\
{[0.002]}\end{array}$ & - \\
\hline$R^{2}$ & 0.272 & 0.279 & 0.235 & 0.088 & 0.279 & 0.272 & 0.279 \\
\hline Observations & 101 & 101 & 101 & 101 & 101 & 101 & 101 \\
\hline
\end{tabular}

$* * *, * * *$ denote $\mathrm{P}<0.01, \mathrm{P}<0.05$ and $\mathrm{P}<0.1$, respectively.

[] denote, robust standard errors, and () represent non-robust standard errors. 
Appendix Table 2 Mozambican Models

\begin{tabular}{|c|c|c|c|c|c|c|c|}
\hline Variable & (1) & $(2)$ & (3) & (4) & (5) & (6) & $(7)$ \\
\hline Constant & $\begin{array}{c}1.556 \\
{[1.135]}\end{array}$ & $\begin{array}{c}2.793 * * \\
{[1.187]}\end{array}$ & $\begin{array}{c}1.237 \\
{[1.096]}\end{array}$ & $\begin{array}{c}\text { 5.319*** } \\
{[0.593]}\end{array}$ & $\begin{array}{c}5.607 * * * \\
{[0.478]}\end{array}$ & $\begin{array}{c}1.262 \\
{[1.084]}\end{array}$ & $\begin{array}{l}\text { 2.183* } \\
{[1.158]}\end{array}$ \\
\hline Broken & - & - & $\begin{array}{c}-0.160 * * * \\
{[0.024]}\end{array}$ & $\begin{array}{c}-0.150 * * * \\
{[0.030]}\end{array}$ & $\begin{array}{c}-0.080 * * \\
{[0.035]}\end{array}$ & $\begin{array}{c}-0.158 * * * \\
{[0.027]}\end{array}$ & $\begin{array}{c}-0.094 * * * \\
{[0.034]}\end{array}$ \\
\hline Length & $\begin{array}{c}0.417 \\
{[0.428]}\end{array}$ & $\begin{array}{c}-0.374 \\
{[0.474]}\end{array}$ & $\begin{array}{c}\mathbf{0 . 4 4 6} \\
{[0.437]}\end{array}$ & - & - & $\begin{array}{c}\mathbf{0 . 4 4 2} \\
{[0.436]}\end{array}$ & $\begin{array}{c}-0.034 \\
{[0.452]}\end{array}$ \\
\hline Width & $\begin{array}{c}1.746 * * \\
{[0.775]}\end{array}$ & $\begin{array}{c}2.251 * * * \\
{[0.658]}\end{array}$ & $\begin{array}{c}2.427 * * * \\
{[0.691]}\end{array}$ & - & - & $\begin{array}{c}2.400 * * * \\
{[0.742]}\end{array}$ & $\begin{array}{c}2.339 * * * \\
{[0.681]}\end{array}$ \\
\hline $\begin{array}{l}\text { Length to } \\
\text { Width ratio }\end{array}$ & - & - & - & $\begin{array}{c}-0.515^{* *} \\
{[0.246]}\end{array}$ & $\begin{array}{c}-0.662 * * * \\
{[0.205]}\end{array}$ & - & - \\
\hline $\begin{array}{l}\text { Chalk } \\
\text { impact }\end{array}$ & - & $\begin{array}{c}-0.114 * * * \\
{[0.017]}\end{array}$ & - & - & $\begin{array}{c}-0.078 * * * \\
{[0.024]}\end{array}$ & - & $\begin{array}{c}-0.065 * * \\
{[0.026]}\end{array}$ \\
\hline Chalky (\%) & $\begin{array}{c}-0.002 * * * \\
{[0.001]}\end{array}$ & - & - & $\begin{array}{r}-0.0005 \\
{[0.001]}\end{array}$ & - & $\begin{array}{c}-0.0001 \\
{[0.001]}\end{array}$ & - \\
\hline $\mathrm{R}^{2}$ & 0.204 & 0.375 & 0.377 & 0.333 & 0.396 & 0.3771 & 0.416 \\
\hline Observations & 112 & 112 & 112 & 112 & 112 & 112 & 112 \\
\hline
\end{tabular}

$* * *, * *, *$ denote $\mathrm{P}<0.01, \mathrm{P}<0.05$ and $\mathrm{P}<0.1$, respectively.

[] denote, robust standard errors, and () represent non-robust standard errors. 
Appendix Table 3 Ghanaian Pooled (Domestic and Imported) Models

\begin{tabular}{|c|c|c|c|c|c|c|c|}
\hline Variable & $(1)$ & $(2)$ & (3) & (4) & (5) & $(6)$ & $(7)$ \\
\hline Constant & $\begin{array}{c}-2.289 * \\
{[1.186]}\end{array}$ & $\begin{array}{c}-2.705^{* *} \\
{[1.180]}\end{array}$ & $\begin{array}{c}-\mathbf{1 . 1 5 1} \\
{[1.194]}\end{array}$ & $\begin{array}{c}1.922 * * * \\
{[0.347]}\end{array}$ & $\begin{array}{c}1.997 * * * \\
{[0.346]}\end{array}$ & $\begin{array}{c}-1.127 \\
{[1.207]}\end{array}$ & $\begin{array}{c}-\mathbf{- 1 . 2 4 9} \\
{[1.219]}\end{array}$ \\
\hline Broken & - & - & $\begin{array}{c}-0.080 * * * \\
{[0.022]}\end{array}$ & $\begin{array}{c}-0.111 * * * \\
{[0.022]}\end{array}$ & $\begin{array}{c}-0.101 * * * \\
{[0.025]}\end{array}$ & $\begin{array}{l}-0.075^{* * *} \\
{[0.025]}\end{array}$ & $\begin{array}{l}-0.082 * * * \\
{[0.022]}\end{array}$ \\
\hline Length & $\begin{array}{c}1.769 * * * \\
{[0.591]}\end{array}$ & $\begin{array}{c}2.036 * * * \\
{[0.583]}\end{array}$ & $\begin{array}{c}1.329 * * \\
{[0.569]}\end{array}$ & - & - & $\begin{array}{c}1.300 * * \\
{[0.581]}\end{array}$ & $\begin{array}{c}1.417^{* *} \\
{[0.582]}\end{array}$ \\
\hline Width & $\begin{array}{c}\mathbf{0 . 8 1 1} * * \\
{[0.401]}\end{array}$ & $\begin{array}{l}\text { 0.719* } \\
{[0.405]}\end{array}$ & $\begin{array}{c}\mathbf{0 . 6 7 1} \\
{[0.409]}\end{array}$ & - & - & $\begin{array}{c}\mathbf{0 . 6 8 7 *} \\
{[0.414]}\end{array}$ & $\begin{array}{c}\mathbf{0 . 5 9 1} \\
{[0.410]}\end{array}$ \\
\hline $\begin{array}{l}\text { Length to } \\
\text { Width ratio }\end{array}$ & - & - & - & $\begin{array}{c}\mathbf{0 . 0 4 8} \\
{[0.152]}\end{array}$ & $\begin{array}{c}0.003 \\
{[0.156]}\end{array}$ & - & - \\
\hline $\begin{array}{l}\text { Chalk } \\
\text { impact }\end{array}$ & - & $\begin{array}{c}0.001 \\
{[0.001]}\end{array}$ & - & $\begin{array}{c}0.001 \\
{[0.002]}\end{array}$ & - & - & $\begin{array}{r}\mathbf{0 . 0 0 2} \\
{[0.001]}\end{array}$ \\
\hline Chalky (\%) & $\begin{array}{c}-0.001 \\
{[0.001]}\end{array}$ & - & - & - & $\begin{array}{c}-0.0005 \\
{[0.001]}\end{array}$ & $\begin{array}{c}-0.0004 \\
{[0.001]}\end{array}$ & - \\
\hline Parboiled & $\begin{array}{c}-0.320 * * * \\
{[0.066]}\end{array}$ & $\begin{array}{c}-0.247 * * * \\
{[0.074]}\end{array}$ & $\begin{array}{c}-0.346 * * * \\
{[0.066]}\end{array}$ & $\begin{array}{c}-0.301 * * * \\
{[0.076]}\end{array}$ & $\begin{array}{c}-0.350 * * * \\
{[0.070]}\end{array}$ & $\begin{array}{l}-0.355^{* * *} \\
{[0.068]}\end{array}$ & $\begin{array}{l}-0.303^{* * *} \\
{[0.076]}\end{array}$ \\
\hline $\mathrm{R}^{2}$ & 0.256 & 0.252 & 0.293 & 0.259 & 0.253 & 0.295 & 0.304 \\
\hline Observations & 150 & 150 & 150 & 150 & 150 & 150 & 150 \\
\hline
\end{tabular}

$* * * * *$, denote $\mathrm{P}<0.01, \mathrm{P}<0.05$ and $\mathrm{P}<0.1$, respectively.

[] denote, robust standard errors, and () represent non-robust standard errors. 
Appendix Table 4 Ghanaian Imported Models

\begin{tabular}{|c|c|c|c|c|c|c|c|}
\hline Variable & $(1)$ & $(2)$ & (3) & (4) & (5) & (6) & (7) \\
\hline Constant & $\begin{array}{l}-2.310 * \\
(1.301)\end{array}$ & $\begin{array}{c}-3.025^{* *} \\
(1.278)\end{array}$ & $\begin{array}{c}-0.824 \\
(1.521)\end{array}$ & $\begin{array}{c}1.221 * * \\
(0.589)\end{array}$ & $\begin{array}{c}1.232 * * \\
(0.586)\end{array}$ & $\begin{array}{l}-0.819 \\
(1.520)\end{array}$ & $\begin{array}{l}-0.810 \\
(1.526)\end{array}$ \\
\hline Broken & - & - & $\begin{array}{c}-0.073 * * \\
(0.030)\end{array}$ & $\begin{array}{c}-0.106 * * * \\
(0.025)\end{array}$ & $\begin{array}{c}-0.089 * * * \\
(0.028)\end{array}$ & $\begin{array}{c}-0.059 * \\
(0.032)\end{array}$ & $\begin{array}{c}-0.075^{* *} \\
(0.030)\end{array}$ \\
\hline Length & $\begin{array}{c}1.790 * * * \\
(0.578)\end{array}$ & $\begin{array}{c}2.092 * * * \\
(0.571)\end{array}$ & $\begin{array}{c}1.377^{* *} \\
(0.621)\end{array}$ & - & - & $\begin{array}{c}1.336 * * \\
(0.621)\end{array}$ & $\begin{array}{c}1.383^{* *} \\
(0.623)\end{array}$ \\
\hline Width & $\begin{array}{c}0.783 \\
(0.792)\end{array}$ & $\begin{array}{c}0.991 \\
(0.800)\end{array}$ & $\begin{array}{c}\mathbf{0 . 1 4 5} \\
(0.850)\end{array}$ & - & - & $\begin{array}{c}0.177 \\
(0.849)\end{array}$ & $\begin{array}{c}0.116 \\
(0.853)\end{array}$ \\
\hline $\begin{array}{l}\text { Length to } \\
\text { Width ratio }\end{array}$ & - & - & - & $\begin{array}{c}0.333 \\
(0.251)\end{array}$ & $\begin{array}{c}0.306 \\
(0.251)\end{array}$ & - & - \\
\hline $\begin{array}{l}\text { Chalk } \\
\text { impact }\end{array}$ & - & $\begin{array}{c}0.001 \\
(0.002)\end{array}$ & - & $\begin{array}{c}0.001 \\
(0.001)\end{array}$ & - & - & $\begin{array}{c}0.001 \\
(0.001)\end{array}$ \\
\hline Chalky (\%) & $\begin{array}{c}-0.001 * \\
(0.001)\end{array}$ & - & - & - & $\begin{array}{l}-0.001 \\
(0.001)\end{array}$ & $\begin{array}{c}-0.001 \\
(0.001)\end{array}$ & - \\
\hline Parboiled & $\begin{array}{c}-0.345^{* * *} \\
(0.084)\end{array}$ & $\begin{array}{c}-0.286 * * * \\
(0.099)\end{array}$ & $\begin{array}{c}-0.313 * * * \\
(0.081)\end{array}$ & $\begin{array}{c}-0.211 * * \\
(0.090)\end{array}$ & $\begin{array}{c}-0.268 * * * \\
(0.077)\end{array}$ & $\begin{array}{c}-0.335^{* * *} \\
(0.083)\end{array}$ & $\begin{array}{c}-0.280 * * * \\
(0.096)\end{array}$ \\
\hline $\mathrm{R}^{2}$ & 0.211 & 0.180 & 0.229 & 0.205 & 0.213 & 0.239 & 0.233 \\
\hline Observations & 96 & 96 & 96 & 96 & 96 & 96 & 96 \\
\hline
\end{tabular}

$* * *, * *, *$ denote $\mathrm{P}<0.01, \mathrm{P}<0.05$ and $\mathrm{P}<0.1$, respectively.

[] denote, robust standard errors, and () represent non-robust standard errors. 
Appendix Table 5 Ghanaian Domestic Models

\begin{tabular}{|c|c|c|c|c|c|c|c|}
\hline Variable & $(1)$ & $(2)$ & (3) & (4) & $(5)$ & (6) & (7) \\
\hline Constant & $\begin{array}{l}-2.472 \\
{[2.897]}\end{array}$ & $\begin{array}{l}-2.061 \\
(2.563)\end{array}$ & $\begin{array}{l}-1.878 \\
{[2.765]}\end{array}$ & $\begin{array}{c}2.327 * * * \\
{[0.721]}\end{array}$ & $\begin{array}{c}2.432 * * * \\
{[0.713]}\end{array}$ & $\begin{array}{c}-1.886 \\
{[2.870]}\end{array}$ & $\begin{array}{l}-1.565 \\
{[2.814]}\end{array}$ \\
\hline Broken & - & - & $\begin{array}{c}-0.144 * \\
{[0.076]}\end{array}$ & $\begin{array}{c}-0.142 * * \\
{[0.070]}\end{array}$ & $\begin{array}{c}-0.153 * * \\
{[0.073]}\end{array}$ & $\begin{array}{c}-0.144^{*} \\
{[0.079]}\end{array}$ & $\begin{array}{c}-0.136 * \\
{[0.075]}\end{array}$ \\
\hline Length & $\begin{array}{c}1.214 \\
{[1.263]}\end{array}$ & $\begin{array}{c}1.121 \\
(1.205)\end{array}$ & $\begin{array}{c}1.514 \\
{[1.293]}\end{array}$ & - & - & $\begin{array}{c}1.515 \\
{[1.324]}\end{array}$ & $\begin{array}{c}1.419 \\
{[1.322]}\end{array}$ \\
\hline Width & $\begin{array}{c}2.175 \\
{[1.408]}\end{array}$ & $\begin{array}{c}1.911 \\
(1.297)\end{array}$ & $\begin{array}{c}1.239 \\
{[1.181]}\end{array}$ & - & - & $\begin{array}{c}1.246 \\
{[1.232]}\end{array}$ & $\begin{array}{c}1.073 \\
{[1.167]}\end{array}$ \\
\hline $\begin{array}{l}\text { Length to } \\
\text { Width ratio }\end{array}$ & & - & - & $\begin{array}{c}-0.082 \\
{[0.355]}\end{array}$ & $\begin{array}{c}-\mathbf{0 . 1 1 9} \\
{[0.353]}\end{array}$ & - & - \\
\hline $\begin{array}{l}\text { Chalk } \\
\text { impact }\end{array}$ & - & $\begin{array}{c}\mathbf{0 . 0 0 3} \\
(0.002)\end{array}$ & - & $\begin{array}{c}\mathbf{0 . 0 0 3} \\
{[0.003]}\end{array}$ & - & - & $\begin{array}{c}\mathbf{0 . 0 0 2} \\
{[0.003]}\end{array}$ \\
\hline Chalky (\%) & $\begin{array}{l}\mathbf{0 . 0 0 0 2} \\
{[0.001]}\end{array}$ & - & - & - & $\begin{array}{c}-0.0001 \\
{[0.001]}\end{array}$ & $\begin{array}{l}0.0001 \\
{[0.001]}\end{array}$ & - \\
\hline Parboiled & $\begin{array}{c}-0.298 * * \\
{[0.120]}\end{array}$ & $\begin{array}{c}-0.265 * * \\
(0.104)\end{array}$ & $\begin{array}{c}-0.393 * * * \\
{[0.124]}\end{array}$ & $\begin{array}{c}-0.415 * * * \\
{[0.134]}\end{array}$ & $\begin{array}{c}-0.470 * * * \\
{[0.142]}\end{array}$ & $\begin{array}{c}-0.392 * * * \\
{[0.145]}\end{array}$ & $\begin{array}{c}-0.353^{* *} \\
{[0.141]}\end{array}$ \\
\hline $\mathrm{R}^{2}$ & 0.297 & 0.322 & 0.343 & 0.334 & 0.308 & 0.343 & 0.363 \\
\hline Observations & 54 & 54 & 54 & 54 & 54 & 54 & 54 \\
\hline
\end{tabular}

$* * *, * *, *$ denote $\mathrm{P}<0.01, \mathrm{P}<0.05$ and $\mathrm{P}<0.1$, respectively.

[] denote, robust standard errors, and () represent non-robust standard errors. 
Appendix Table 6 Democratic Republic of the Congo Models with Market Fixed Effects

\begin{tabular}{|c|c|c|c|c|c|c|c|}
\hline Variable & (1) & (2) & (3) & (4) & (5) & (6) & (7) \\
\hline Constant & $\begin{array}{c}4.067 * * * \\
{[1.309]}\end{array}$ & $\begin{array}{c}3.779 * * * \\
{[1.240]}\end{array}$ & $\begin{array}{c}3.729 * * * \\
{[1.289]}\end{array}$ & $\begin{array}{c}7.419 * * * \\
{[0.467]}\end{array}$ & $\begin{array}{c}7.490 * * * \\
{[0.417]}\end{array}$ & $\begin{array}{c}4.075 * * * \\
{[1.325]}\end{array}$ & $\begin{array}{c}3.804 * * * \\
{[1.259]}\end{array}$ \\
\hline Broken & - & - & $\begin{array}{c}-0.013 \\
{[0.029]}\end{array}$ & $\begin{array}{c}-0.002 \\
{[0.035]}\end{array}$ & $\begin{array}{c}-0.011 \\
{[0.029]}\end{array}$ & $\begin{array}{l}-0.005 \\
{[0.036]}\end{array}$ & $\begin{array}{c}-0.012 \\
{[0.031]}\end{array}$ \\
\hline Length & $\begin{array}{c}1.046 * * \\
{[0.470]}\end{array}$ & $\begin{array}{c}1.094 * * \\
{[0.455]}\end{array}$ & $\begin{array}{c}1.115^{* *} \\
{[0.484]}\end{array}$ & - & - & $\begin{array}{c}1.040 * * \\
{[0.481]}\end{array}$ & $\begin{array}{c}1.079 * * \\
{[0.464]}\end{array}$ \\
\hline Width & $\begin{array}{c}1.633 * * \\
{[0.782]}\end{array}$ & $\begin{array}{c}1.817^{* *} \\
{[0.722]}\end{array}$ & $\begin{array}{c}1.913 * * \\
{[0.736]}\end{array}$ & - & - & $\begin{array}{c}1.651 * * \\
{[0.800]}\end{array}$ & $\begin{array}{c}1.855^{* *} \\
{[0.722]}\end{array}$ \\
\hline $\begin{array}{l}\text { Length to } \\
\text { Width ratio }\end{array}$ & - & - & - & $\begin{array}{c}\mathbf{0 . 0 1 8} \\
{[0.162]}\end{array}$ & $\begin{array}{c}-0.025 \\
{[0.144]}\end{array}$ & - & - \\
\hline $\begin{array}{l}\text { Chalk } \\
\text { impact }\end{array}$ & - & $\begin{array}{l}\text { 0.034* } \\
{[0.020]}\end{array}$ & - & - & $\begin{array}{l}0.041 * \\
{[0.022]}\end{array}$ & - & $\begin{array}{c}\mathbf{0 . 0 3 4} \\
{[0.021]}\end{array}$ \\
\hline Chalky (\%) & $\begin{array}{c}-0.002 \\
{[0.001]}\end{array}$ & - & - & $\begin{array}{c}-0.002 \\
{[0.001]}\end{array}$ & - & $\begin{array}{c}-0.002 \\
{[0.001]}\end{array}$ & - \\
\hline Bag Central & $\begin{array}{l}-0.213 \\
{[0.203]}\end{array}$ & $\begin{array}{l}-0.206 \\
{[0.197]}\end{array}$ & $\begin{array}{l}-0.220 \\
{[0.203]}\end{array}$ & $\begin{array}{l}-0.229 \\
{[0.237]}\end{array}$ & $\begin{array}{c}-0.226 \\
{[0.232]}\end{array}$ & $\begin{array}{l}-0.216 \\
{[0.206]}\end{array}$ & $\begin{array}{c}-0.211 \\
{[0.200]}\end{array}$ \\
\hline Bagira & $\begin{array}{l}-0.206 \\
{[0.198]}\end{array}$ & $\begin{array}{c}-0.199 \\
{[0.189]}\end{array}$ & $\begin{array}{l}-0.200 \\
{[0.195]}\end{array}$ & $\begin{array}{c}-0.268 \\
{[0.234]}\end{array}$ & $\begin{array}{c}-0.265 \\
{[0.228]}\end{array}$ & $\begin{array}{l}-0.205 \\
{[0.199]}\end{array}$ & $\begin{array}{c}-0.199 \\
{[0.190]}\end{array}$ \\
\hline Brasserie & $\begin{array}{l}-0.211 \\
{[0.198]}\end{array}$ & $\begin{array}{l}-0.203 \\
{[0.190]}\end{array}$ & $\begin{array}{l}-0.212 \\
{[0.196]}\end{array}$ & $\begin{array}{l}-0.238 \\
{[0.234]}\end{array}$ & $\begin{array}{l}-0.233 \\
{[0.228]}\end{array}$ & $\begin{array}{l}-0.212 \\
{[0.200]}\end{array}$ & $\begin{array}{l}-0.205 \\
{[0.191]}\end{array}$ \\
\hline Buholoi & $\begin{array}{c}-0.170 \\
{[0.200]}\end{array}$ & $\begin{array}{c}-0.163 \\
{[0.191]}\end{array}$ & $\begin{array}{c}-0.171 \\
{[0.198]}\end{array}$ & $\begin{array}{c}-0.192 \\
{[0.237]}\end{array}$ & $\begin{array}{c}-0.187 \\
{[0.230]}\end{array}$ & $\begin{array}{c}-0.171 \\
{[0.202]}\end{array}$ & $\begin{array}{c}-0.165 \\
{[0.192]}\end{array}$ \\
\hline Cimpunda & $\begin{array}{c}-0.234 \\
{[0.201]}\end{array}$ & $\begin{array}{c}-0.210 \\
{[0.190]}\end{array}$ & $\begin{array}{l}-0.222 \\
{[0.197]}\end{array}$ & $\begin{array}{c}-0.228 \\
{[0.238]}\end{array}$ & $\begin{array}{c}-0.199 \\
{[0.230]}\end{array}$ & $\begin{array}{l}-0.235 \\
{[0.203]}\end{array}$ & $\begin{array}{c}-0.212 \\
{[0.192]}\end{array}$ \\
\hline Kadutu & $\begin{array}{l}-0.192 \\
{[0.199]}\end{array}$ & $\begin{array}{l}-0.180 \\
{[0.191]}\end{array}$ & $\begin{array}{c}-0.181 \\
{[0.197]}\end{array}$ & $\begin{array}{c}-0.207 \\
{[0.236]}\end{array}$ & $\begin{array}{c}-0.194 \\
{[0.230]}\end{array}$ & $\begin{array}{c}-0.192 \\
{[0.201]}\end{array}$ & $\begin{array}{c}-0.181 \\
{[0.192]}\end{array}$ \\
\hline Muhanzi & $\begin{array}{c}-0.191 \\
{[0.199]}\end{array}$ & $\begin{array}{c}-0.169 \\
{[0.191]}\end{array}$ & $\begin{array}{c}-0.174 \\
{[0.196]}\end{array}$ & $\begin{array}{c}-0.250 \\
{[0.235]}\end{array}$ & $\begin{array}{c}-0.228 \\
{[0.228]}\end{array}$ & $\begin{array}{c}-0.192 \\
{[0.200]}\end{array}$ & $\begin{array}{c}-0.170 \\
{[0.192]}\end{array}$ \\
\hline Nguba & $\begin{array}{l}-0.119 \\
{[0.201]}\end{array}$ & $\begin{array}{l}-0.125 \\
{[0.191]}\end{array}$ & $\begin{array}{l}-0.128 \\
{[0.199]}\end{array}$ & $\begin{array}{c}-0.095 \\
{[0.238]}\end{array}$ & $\begin{array}{c}-0.103 \\
{[0.231]}\end{array}$ & $\begin{array}{c}-0.122 \\
{[0.204]}\end{array}$ & $\begin{array}{l}-0.130 \\
{[0.193]}\end{array}$ \\
\hline Nyawera & $\begin{array}{l}-0.029 \\
{[0.206]}\end{array}$ & $\begin{array}{c}-0.022 \\
{[0.197]}\end{array}$ & $\begin{array}{l}-0.014 \\
{[0.204]}\end{array}$ & $\begin{array}{c}-0.041 \\
{[0.246]}\end{array}$ & $\begin{array}{c}-0.032 \\
{[0.239]}\end{array}$ & $\begin{array}{l}-0.029 \\
{[0.207]}\end{array}$ & $\begin{array}{c}-0.023 \\
{[0.198]}\end{array}$ \\
\hline $\mathrm{R}^{2}$ & 0.447 & 0.434 & 0.415 & 0.350 & 0.320 & 0.447 & 0.435 \\
\hline Observations & 101 & 101 & 101 & 101 & 101 & 101 & 101 \\
\hline
\end{tabular}

$* * *, * *, *$ denote $\mathrm{P}<0.01, \mathrm{P}<0.05$ and $\mathrm{P}<0.1$, respectively.

[] denote, robust standard errors, and () represent non-robust standard errors. 
Appendix Table 7 Mozambican Models with Market Fixed Effects

\begin{tabular}{|c|c|c|c|c|c|c|c|}
\hline Variable & $(1)$ & $(2)$ & (3) & (4) & (5) & (6) & (7) \\
\hline Constant & $\begin{array}{c}0.707 \\
(1.259)\end{array}$ & $\begin{array}{l}2.051 * \\
(1.139)\end{array}$ & $\begin{array}{c}\mathbf{0 . 4 6 2} \\
(1.081)\end{array}$ & $\begin{array}{c}5.334 * * * \\
(0.427)\end{array}$ & $\begin{array}{c}5.646 * * * \\
{[0.558]}\end{array}$ & $\begin{array}{c}0.470 \\
(1.095)\end{array}$ & $\begin{array}{c}1.319 \\
(1.116)\end{array}$ \\
\hline Broken & - & - & $\begin{array}{c}-0.170 * * * \\
(0.024)\end{array}$ & $\begin{array}{c}-0.161 * * * \\
(0.031)\end{array}$ & $\begin{array}{c}-0.090 * * * \\
{[0.034]}\end{array}$ & $\begin{array}{c}-0.169 * * * \\
(0.029)\end{array}$ & $\begin{array}{c}-0.109 * * * \\
(0.035)\end{array}$ \\
\hline Length & $\begin{array}{c}0.688 \\
(0.491)\end{array}$ & $\begin{array}{l}-0.155 \\
(0.454)\end{array}$ & $\begin{array}{c}\mathbf{0 . 6 5 0} \\
(0.425)\end{array}$ & - & - & $\begin{array}{c}0.650 \\
(0.427)\end{array}$ & $\begin{array}{c}\mathbf{0 . 2 2 8} \\
(0.452)\end{array}$ \\
\hline Width & $\begin{array}{c}2.004 * * * \\
(0.641)\end{array}$ & $\begin{array}{c}2.561 * * * \\
(0.547)\end{array}$ & $\begin{array}{c}2.745 * * * \\
(0.537)\end{array}$ & - & - & $\begin{array}{c}2.735 * * * \\
(0.571)\end{array}$ & $\begin{array}{c}2.679 * * * \\
(0.526)\end{array}$ \\
\hline $\begin{array}{l}\text { Length to } \\
\text { Width ratio }\end{array}$ & - & - & - & $\begin{array}{c}-0.555^{* * *} \\
(0.168)\end{array}$ & $\begin{array}{c}-0.699 * * * \\
{[0.219]}\end{array}$ & - & - \\
\hline $\begin{array}{l}\text { Chalk } \\
\text { impact }\end{array}$ & - & $\begin{array}{c}-0.114 * * * \\
(0.017)\end{array}$ & - & - & $\begin{array}{c}-0.077^{* * *} \\
{[0.025]}\end{array}$ & - & $\begin{array}{c}-0.058 * * \\
(0.024)\end{array}$ \\
\hline Chalky (\%) & $\begin{array}{c}-0.002 * * * \\
(0.001)\end{array}$ & - & - & $\begin{array}{c}-0.0004 \\
(0.001)\end{array}$ & - & $\begin{array}{c}-0.00004 \\
(0.001)\end{array}$ & - \\
\hline Bamboo & $\begin{array}{c}\mathbf{0 . 1 6 9} \\
(0.136)\end{array}$ & $\begin{array}{c}\mathbf{0 . 0 9 3} \\
(0.120)\end{array}$ & $\begin{array}{c}\mathbf{0 . 1 5 6} \\
(0.117)\end{array}$ & $\begin{array}{c}\mathbf{0 . 1 2 3} \\
(0.123)\end{array}$ & $\begin{array}{c}\mathbf{0 . 0 8 7} \\
{[0.210]}\end{array}$ & $\begin{array}{c}\mathbf{0 . 1 5 6} \\
(0.118)\end{array}$ & $\begin{array}{c}\mathbf{0 . 1 2 0} \\
(0.116)\end{array}$ \\
\hline Belonensese & $\begin{array}{c}0.065 \\
(0.129)\end{array}$ & $\begin{array}{c}0.031 \\
(0.114)\end{array}$ & $\begin{array}{c}\mathbf{0 . 0 9 0} \\
(0.111)\end{array}$ & $\begin{array}{c}0.078 \\
(0.118)\end{array}$ & $\begin{array}{c}0.044 \\
{[0.206]}\end{array}$ & $\begin{array}{c}0.089 \\
(0.112)\end{array}$ & $\begin{array}{c}\mathbf{0 . 0 5 8} \\
(0.110)\end{array}$ \\
\hline Coto Quani & $\begin{array}{c}0.148 \\
(0.127)\end{array}$ & $\begin{array}{c}0.096 \\
(0.113)\end{array}$ & $\begin{array}{c}\mathbf{0 . 1 7 3} \\
(0.110)\end{array}$ & $\begin{array}{c}0.138 \\
(0.116)\end{array}$ & $\begin{array}{c}\mathbf{0 . 1 0 0} \\
{[0.204]}\end{array}$ & $\begin{array}{c}0.173 \\
(0.111)\end{array}$ & $\begin{array}{c}\mathbf{0 . 1 3 4} \\
(0.109)\end{array}$ \\
\hline Moconvela & $\begin{array}{c}0.124 \\
(0.132)\end{array}$ & $\begin{array}{c}0.109 \\
(0.117)\end{array}$ & $\begin{array}{l}0.205^{*} \\
(0.115)\end{array}$ & $\begin{array}{c}0.166 \\
(0.121)\end{array}$ & $\begin{array}{c}0.133 \\
{[0.207]}\end{array}$ & $\begin{array}{l}0.204 * \\
(0.116)\end{array}$ & $\begin{array}{c}\mathbf{0 . 1 6 8} \\
(0.114)\end{array}$ \\
\hline Mohala & $\begin{array}{c}0.060 \\
(0.127)\end{array}$ & $\begin{array}{c}\mathbf{0 . 0 1 9} \\
(0.112)\end{array}$ & $\begin{array}{c}0.075 \\
(0.110)\end{array}$ & $\begin{array}{c}0.044 \\
(0.116)\end{array}$ & $\begin{array}{c}\mathbf{0 . 0 1 7} \\
{[0.204]}\end{array}$ & $\begin{array}{c}\mathbf{0 . 0 7 4} \\
(0.111)\end{array}$ & $\begin{array}{c}\mathbf{0 . 0 4 6} \\
(0.108)\end{array}$ \\
\hline Mehevere & $\begin{array}{l}-0.007 \\
(0.144)\end{array}$ & $\begin{array}{l}-0.075 \\
(0.127)\end{array}$ & $\begin{array}{c}\mathbf{0 . 0 1 3} \\
(0.125)\end{array}$ & $\begin{array}{c}\mathbf{0 . 0 0 6} \\
(0.131)\end{array}$ & $\begin{array}{c}-0.047 \\
{[0.212]}\end{array}$ & $\begin{array}{c}\mathbf{0 . 0 1 3} \\
(0.125)\end{array}$ & $\begin{array}{l}-0.027 \\
(0.123)\end{array}$ \\
\hline Pinto & $\begin{array}{c}0.104 \\
(0.132)\end{array}$ & $\begin{array}{c}0.043 \\
(0.117)\end{array}$ & $\begin{array}{c}0.139 \\
(0.114)\end{array}$ & $\begin{array}{c}\mathbf{0 . 1 2 8} \\
(0.120)\end{array}$ & $\begin{array}{c}\mathbf{0 . 0 7 2} \\
{[0.213]}\end{array}$ & $\begin{array}{c}0.139 \\
(0.115)\end{array}$ & $\begin{array}{c}0.092 \\
(0.113)\end{array}$ \\
\hline Rapale & $\begin{array}{c}\mathbf{0 . 1 5 5} \\
(0.134)\end{array}$ & $\begin{array}{c}\mathbf{0 . 0 9 4} \\
(0.119)\end{array}$ & $\begin{array}{c}\mathbf{0 . 1 5 3} \\
(0.116)\end{array}$ & $\begin{array}{c}\mathbf{0 . 0 9 8} \\
(0.121)\end{array}$ & $\begin{array}{c}\mathbf{0 . 0 7 5} \\
{[0.207]}\end{array}$ & $\begin{array}{c}\mathbf{0 . 1 5 3} \\
(0.117)\end{array}$ & $\begin{array}{c}\mathbf{0 . 1 2 3} \\
(0.114)\end{array}$ \\
\hline $\mathrm{R}^{2}$ & 0.267 & 0.429 & 0.451 & 0.391 & 0.448 & 0.451 & 0.481 \\
\hline Observations & 112 & 112 & 112 & 112 & 112 & 112 & 112 \\
\hline
\end{tabular}

$* * *, * *, *$ denote $\mathrm{P}<0.01, \mathrm{P}<0.05$ and $\mathrm{P}<0.1$, respectively.

[] denote, robust standard errors, and () represent non-robust standard errors. 
Appendix Table 8 Ghanaian Models with Market Fixed Effects

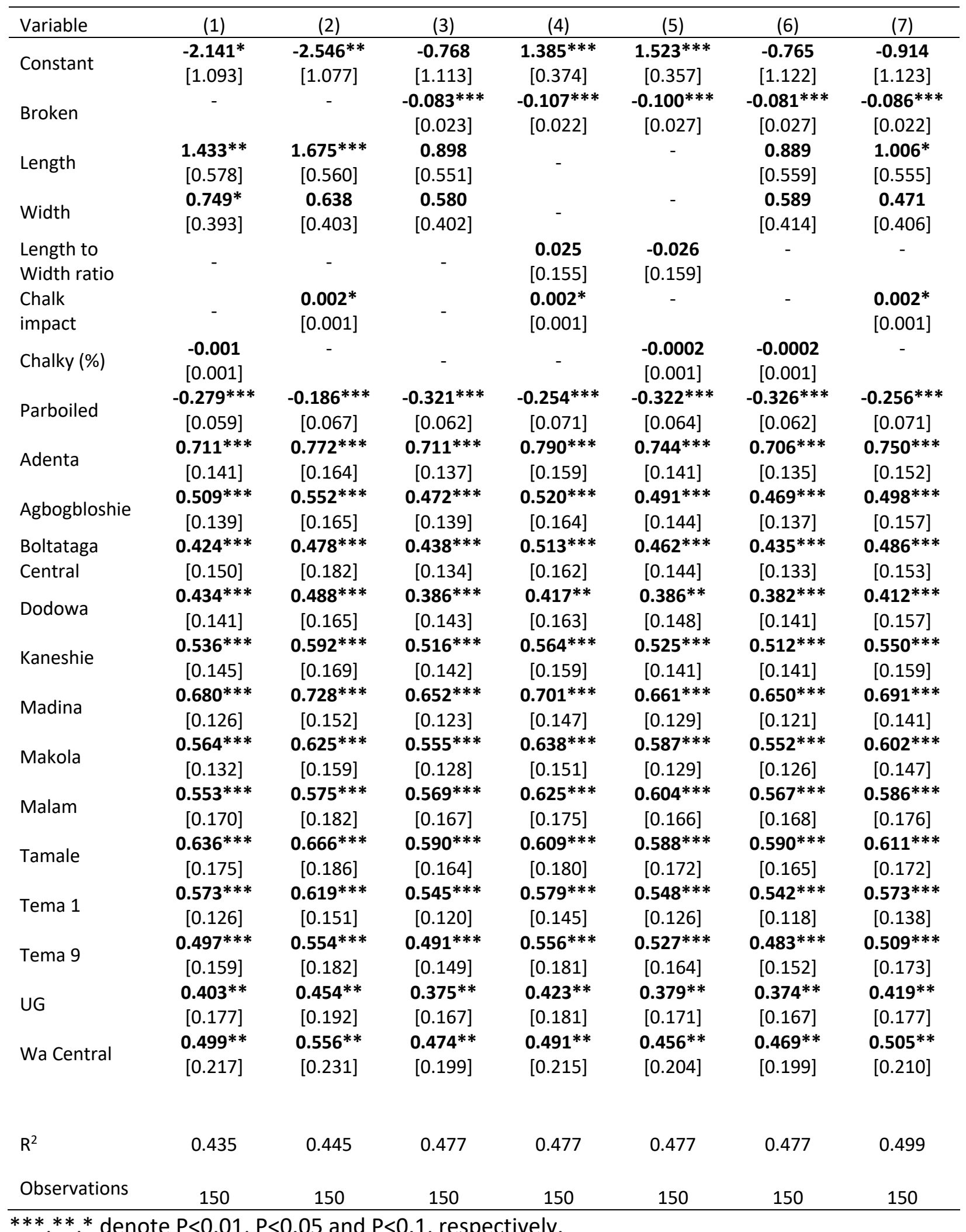

$* * *, * *$, denote $\mathrm{P}<0.01, \mathrm{P}<0.05$ and $\mathrm{P}<0.1$, respectively.

[] denote, robust standard errors, and () represent non-robust standard errors. 